\title{
The hygroscopicity parameter $(\kappa)$ of ambient organic aerosol at a field site subject to biogenic and anthropogenic influences: relationship to degree of aerosol oxidation
}

\author{
R. Y.-W. Chang ${ }^{1}$, J. G. Slowik ${ }^{1}$, N. C. Shantz ${ }^{1, *}$, A. Vlasenko ${ }^{1, *}$, J. Liggio ${ }^{2}$, S. J. Sjostedt ${ }^{1, *}$, W. R. Leaitch ${ }^{2}$, and \\ J. P. D. Abbatt ${ }^{1}$ \\ ${ }^{1}$ Department of Chemistry, University of Toronto, Toronto, Canada \\ ${ }^{2}$ Science and Technology Branch, Environment Canada, Downsview, Canada \\ * now at: Science and Technology Branch, Environment Canada, Downsview, Canada
}

Received: 3 November 2009 - Published in Atmos. Chem. Phys. Discuss.: 25 November 2009

Revised: 17 May 2010 - Accepted: 24 May 2010 - Published: 1 June 2010

\begin{abstract}
Cloud condensation nuclei (CCN) concentrations were measured at Egbert, a rural site in Ontario, Canada during the spring of 2007. The CCN concentrations were compared to values predicted from the aerosol chemical composition and size distribution using $\kappa$-Köhler theory, with the specific goal of this work being to determine the hygroscopic parameter $(\kappa)$ of the oxygenated organic component of the aerosol, assuming that oxygenation drives the hygroscopicity for the entire organic fraction of the aerosol. The hygroscopicity of the oxygenated fraction of the organic component, as determined by an Aerodyne aerosol mass spectrometer (AMS), was characterised by two methods. First, positive matrix factorization (PMF) was used to separate oxygenated and unoxygenated organic aerosol factors. By assuming that the unoxygenated factor is completely non-hygroscopic and by varying $\kappa$ of the oxygenated factor so that the predicted and measured $\mathrm{CCN}$ concentrations are internally consistent and in good agreement, $\kappa$ of the oxygenated organic factor was found to be $0.22 \pm 0.04$ for the suite of measurements made during this five-week campaign. In a second, equivalent approach, we continue to assume that the unoxygenated component of the aerosol, with a mole ratio of atomic oxygen to atomic carbon $(\mathrm{O} / \mathrm{C}) \approx 0$, is completely non-hygroscopic, and we postulate a simple linear relationship between $\kappa_{\text {org }}$ and $\mathrm{O} / \mathrm{C}$. Under these assumptions, the $\kappa$ of the entire organic component for bulk aerosols measured by the AMS can be parameterised as $\kappa_{\mathrm{org}}=(0.29 \pm 0.05) \cdot(\mathrm{O} / \mathrm{C})$, for the range of
\end{abstract}

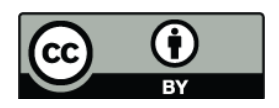

Correspondence to: R. Y.-W. Chang (rchang@chem.utoronto.ca)
$\mathrm{O} / \mathrm{C}$ observed in this study ( 0.3 to 0.6 ). These results are averaged over our five-week study at one location using only the AMS for composition analysis. Empirically, our measurements are consistent with $\kappa_{\text {org }}$ generally increasing with increasing particle oxygenation, but high uncertainties preclude us from testing this hypothesis. Lastly, we examine select periods of different aerosol composition, corresponding to different air mass histories, to determine the generality of the campaign-wide findings described above.

\section{Introduction}

Atmospheric aerosols can affect climate directly by scattering and absorbing incoming solar radiation, or indirectly by acting as cloud condensation nuclei (CCN), which form clouds and in turn can reflect light (Twomey, 1977). The efficiency of particles as CCN also affects both aerosol particle and cloud droplet lifetimes (Albrecht, 1989). It is well recognised that these effects represent one of the largest uncertainties in assessing the changes in radiative forcing from pre-industrial times to the present (Solomon et al., 2007). As such, understanding the hygroscopic properties of aerosols and the processes that govern cloud droplet activation are important.

Köhler theory has been used to predict the $\mathrm{CCN}$-activity of inorganic compounds for many years (Köhler, 1936). In the last decade, the focus has turned to the prediction of the $\mathrm{CCN}$-activity of organic compounds in atmospheric particles. Laboratory studies have shown that the $\mathrm{CCN}$ activity of organic, inorganic, or mixed aerosol systems can

Published by Copernicus Publications on behalf of the European Geosciences Union. 
be predicted if the composition of the particles is wellcharacterised and their properties are known (Abbatt et al., 2005; Bilde and Svenningsson, 2004; Broekhuizen et al., 2004a; Raymond and Pandis, 2002, 2003). However, ambient aerosols are composed of numerous organic compounds that are difficult to identify and quantify (Jacobson et al., 2000; Saxena and Hildemann, 1996), therefore complicating the prediction of the $\mathrm{CCN}$-activity of those ambient particles. The organic fraction comprises a significant fraction of the aerosol at many locations in the Northern Hemisphere (Zhang et al., 2007), highlighting the need to study organic aerosol hygroscopicity. In this study, we conduct an aerosolCCN closure study of ambient aerosols at a continental site, in which we compare $\mathrm{CCN}$ concentrations measured using a $\mathrm{CCN}$ counter with those predicted using modified Köhler theory aiming to better describe the hygroscopicity of the organic components of the particles.

Two strategies are used in this paper to simplify the experimental approach to studying this aerosol property. These approaches reflect recent major developments in the aerosol field. First, field observations of the organic aerosol made by an aerosol mass spectrometer (AMS) are characterised by the degree of oxygenation. One method of doing this is by using the molar ratio of atomic oxygen to atomic carbon $(\mathrm{O} / \mathrm{C})$ as measured by the AMS to represent the aerosol's degree of oxygenation (Aiken et al., 2008). Another method is to use factor analysis techniques such as the recently more popular positive matrix factorization (PMF) (Lanz et al., 2007; Ulbrich et al., 2009) to separate the oxygenated and unoxygenated components. Here, aerosol mass spectra, which contain signals from hundreds if not thousands of organic molecules, are described as a linear combination of a few characteristic factors relating to emission sources, atmospheric processing, etc. This approach characterises the overall organic composition in terms of a sufficiently small number of factors that might match the number of organic aerosol species specified in climate and air quality models, such as the hydrophilic and hydrophobic organic fractions used in some global models (Chung and Seinfeld, 2002; Cooke and Wilson, 1996; Lohmann et al., 1999). A combination of AMS measurements (Zhang et al., 2007) and the subsequent application of PMF (Lanz et al., 2007; U1brich et al., 2009) is now a common approach used in the organic aerosol community.

The second simplifying advance of which we take advantage is to describe the organic hygroscopicity using the $\kappa$-Köhler method (Petters and Kreidenweis, 2007, 2008). Specifically, this expression of the Köhler model groups the properties of each compound present in the aerosol particle that affects its hygroscopicity into a single variable, $\kappa$. Thus, knowledge of the individual chemical properties (e.g. molecular solubility, molecular weight), which are largely unknown in ambient aerosol, is obviated. And so, as described in detail below, the specific goal of this work is to determine the hygroscopic properties (expressed as the $\kappa$ parameter) of the oxygenated organic component of the aerosol, under the assumption that the oxygenated component drives the hygroscopicity for the entire organic fraction of the aerosol.

An extensive review of early aerosol-CCN closure studies that had limited information about the organic component of the aerosol can be found in Broekhuizen et al. (2006). However, with the recent widespread use of the AMS and following the initial study of Broekhuizen et al. (2006), a few closure studies have since been conducted in which the aerosol chemical composition is highly time resolved and the organic fraction quantified. These studies from the field achieved closure by determining the hygroscopicity of either the entire aerosol by assuming an average chemical composition in continental China (Rose et al., 2010), or the entire organic component by assuming that the hygroscopicity in the organic component was constant at rural locations (Chang et al., 2007; Medina et al., 2007; Stroud et al., 2007), in the Amazon (Gunthe et al., 2009; Roberts et al., 2002), at cloud level (Wang et al., 2008), as well as sites that are removed from major source areas (Ervens et al., 2010). A general conclusion is that the organic fraction is hygroscopic. This contrasts with urban closure studies indicating insoluble organics (Lance et al., 2009), especially at small sizes (e.g. Broekhuizen et al., 2006; Cubison et al., 2008; Quinn et al., 2008), although this can also be true for remote locations (Ervens et al., 2007). Here we conduct a study of the hygroscopicity of the organic component at supersaturated conditions, focusing on the oxygenated component under the assumption that the unoxygenated component is non-hygroscopic. Similar results have been published for subsaturated conditions (McFiggans et al., 2005; Raatikainen et al., 2010) and more recently for laboratory and ambient measurements (Jimenez et al., 2009), although laboratory experiments have shown that organic aerosol hygroscopicity under subsaturated conditions can be lower than under supersaturated conditions (Petters et al., 2009b; Prenni et al., 2007; Wex et al., 2009). This study builds on the results from previous closure studies conducted in our group at urban and rural sites (Broekhuizen et al., 2006; Chang et al., 2007).

\section{Experimental method}

The Egbert 2007 study took place between 14 May and 15 June 2007, at Environment Canada's Centre for Atmospheric Research and Experiment (CARE). This rural site, situated at Egbert, Ontario, Canada (44.23 N, 79.78 W, $251 \mathrm{~m}$ above sea level), approximately $70 \mathrm{~km}$ north of Toronto, is surrounded by farmland, and experiences minimal influence from local sources. The actual sampling location is $125 \mathrm{~m}$ from the main CARE building and the nearest road, $75 \mathrm{~m}$ away, is used by only a few vehicles per hour. The site is often impacted by polluted urban outflow from the populated and industrialised regions of Southwestern Ontario and 
mid-western United States, as well as cleaner continental air from the north (Rupakheti et al., 2005).

The overall goal of Egbert 2007 was to improve our understanding of the sources and hygroscopicity of organic aerosols. To this end, recent publications from this campaign have shown that the oxidation state of the aerosol correlates with the photochemical age of the air (Vlasenko et al., 2009), significant secondary organic aerosol (SOA) mass can be formed from monoterpene oxidation (Slowik et al., 2010), oxygenated organic aerosols from anthropogenicallyinfluenced air could have primary and secondary sources, while biogenically-influenced air only had secondary sources (Chan et al., 2010), and aerosols from anthropogenicallyinfluenced air showed a delay in cloud droplet activation compared to biogenically-influenced air (Shantz et al., 2010). The present study focuses on the hygroscopicity of the organic component of the aerosol by performing an aerosol$\mathrm{CCN}$ closure experiment alongside measurements of the organic component of the gas and particulate phases, so as to best define the source of air sampled at CARE. A wide variety of instruments were deployed during the study, but only those of direct relevance to this analysis are described here.

\subsection{Scanning mobility particle sizer}

A scanning mobility particle sizer (SMPS, TSI 3071, 3081, 3010) measured aerosol size distributions between $10 \mathrm{~nm}$ and $420 \mathrm{~nm}$ in diameter every $15 \mathrm{~min}$ with a sample to sheath flow ratio of 1:6, where the sheath flow was dried with silica gel. All instruments sampled from the roof of the building, with intakes $\approx 5.5 \mathrm{~m}$ above ground. The main inlet was a PVC pipe ( $0.2 \mathrm{~m}$ inner diameter), lined with aluminium tape to decrease electrostatic deposition, where the residence time was $\approx 1 \mathrm{~min}$. The SMPS sampled from the central axis of the main inlet in stainless steel tubing with a residence time of the secondary lines of $\approx 1 \mathrm{~s}$.

\subsection{CCN counter}

The CCN concentration was measured at a constant supersaturation using a parallel-plate continuous flow thermal gradient diffusion chamber that was previously used in a closure study at the same site (Chang et al., 2007). This instrument, built at the University of Toronto, is a more portable and automated version of the design described by Pradeep Kumar et al. (2003). It consists of two parallel aluminium plates held at different temperatures, which results in a supersaturation forming at the centre of the chamber (Saxena et al., 1970). A sheath flow $\left(1.8 \mathrm{~L} \mathrm{~min}^{-1}\right)$ keeps the sample aerosol flow $\left(0.2 \mathrm{~L} \mathrm{~min}^{-1}\right)$ at the centre of the chamber such that particles that are $\mathrm{CCN}$-active at that supersaturation activate and are counted by an aerodynamic particle sizer (APS, TSI 3320) as they exit the chamber. The cooler bottom plate was maintained at room temperature while the warmer upper plate was actively heated with a resistive heating pad (Omega) to the temperature required for the desired supersaturation as calculated and controlled by a Labview (National Instruments) program from the temperature of the cooler bottom plate. Like the chamber described by Pradeep Kumar et al. (2003), this instrument has a movable injector that allows the residence time to vary from 9 to $21 \mathrm{~s}$. The residence time of the chamber was adjusted to optimise the $\mathrm{CCN}$ concentration, which, for most of this study, occurred at $19 \mathrm{~s}$. This time is a balance between giving the droplets sufficient time to grow to sizes large enough to be counted by the APS and preventing the aerosols from growing so large that they are lost to gravitational settling. The optimal residence time can also depend on the aerosol chemical composition. This effect was not explored systematically during this study, although Shantz et al. (2010) discuss the kinetics of activation during the Egbert 2007 study.

The CCN counter was calibrated four times throughout the study using monodisperse ammonium sulphate particles to determine the activation diameter (i.e. the size at which 50\% of the aerosols activate). Based on these calibrations and water activity coefficients from Clegg et al. (1996), the effective supersaturation in the chamber was determined to be $0.42 \pm 0.04 \%$. This instrument also sampled from the main inlet with a residence time in its secondary line of $<6 \mathrm{~s}$. The uncertainties in the CCN counter are estimated to be $\pm 20 \%$, principally based on the uncertainties in the APS counter and sample flow rate.

\subsection{Proton-transfer-reaction mass spectrometer}

Volatile organic compounds (VOCs) were measured using a proton-transfer-reaction mass spectrometer (PTR-MS, Ionicon Analytik). The details of this method and its application to ambient air sampling have been described elsewhere (de Gouw and Warneke, 2007). A description of the instrument performance during this particular study can be found in Vlasenko et al. (2009). In brief, ambient air was sampled at $4.4 \mathrm{~L} \mathrm{~min}^{-1}$ through a $7.5 \mathrm{~m}$ long PFA tube with $0.48 \mathrm{~cm}$ inner diameter whose inlet was $2 \mathrm{~m}$ from the main aerosol inlet. The PTR-MS sampled $0.2 \mathrm{~L} \mathrm{~min}^{-1}$ from the main flow through a heated $0.2 \mathrm{~cm}$ outer diameter silcosteel line. Protonated VOC species were recorded in scanning mode from $\mathrm{m} / \mathrm{z} 21$ to 160 on a $140 \mathrm{~s}$ time interval. The system was calibrated by standard addition using commercial custommade gas mixtures (Apel-Riemer Inc. and Scott Specialty Gases). In addition, background measurements were made by installing a charcoal cartridge (Supelco) upstream of the PTR-MS inlet line.

\subsection{Aerosol mass spectrometers}

A time-of-flight aerosol mass spectrometer (C-ToF AMS, Aerodyne) measured the aerosol chemical composition that was non-refractory at $870 \mathrm{~K}$ and $10^{-7}$ torr. The operation 
of the AMS has been described elsewhere (Drewnick et al., 2005; Jayne et al., 2000; Jimenez et al., 2003) and the specific operation of this instrument for this study is described by Slowik et al. (2010). This AMS sampled off a separate stainless steel and copper inlet $\approx 3 \mathrm{~m}$ from the main inlet with a residence time of $\approx 15 \mathrm{~s}$. In this analysis, the bulk aerosol mass spectrum was used instead of the mass size distribution data because the PMF analysis, described below, was performed on the bulk data and is thus more representative of the entire aerosol. In addition, the signal was quite low at sizes $<100 \mathrm{~nm}$ diameter, which is the typical activation diameter, resulting in a low signal to noise. Using the bulk mass spectra assumes that the aerosol is internally mixed. This is not unreasonable since the mass distributions were mostly unimodal and there were no significant local sources at the sampling site, although uncertainties from this assumption will be addressed in Sect. 4.3.

AMS mass concentration measurements are complicated by uncertainties in collection efficiency due to the possibility of particle bounce at the vaporiser surface that can vary with chemical composition. In general, this does not affect the analysis below, which only uses the fractional composition and assumes an internally mixed aerosol. If the aerosol were not internally mixed, then the collection efficiency could be important, and potential effects will be considered in Sect. 4.3 by considering relative uncertainties in the organic to inorganic ratios.

The PMF receptor modelling technique uses multivariate statistical methods to represent an input data matrix as a linear combination of a set of factor profiles (mass spectra, for AMS data) and their time-dependent intensities (Paatero, 1997; Paatero and Tapper, 1994). Application of PMF to AMS datasets have previously been discussed (Allan et al., 2010; Lanz et al., 2007; Slowik et al., 2009; Ulbrich et al., 2009), as has the PMF analysis for the present study (Slowik et al., 2010). In the present study, four factors were resolved for the organic component: a hydrocarbon-like organic aerosol (HOA) component correlating with tracers for primary anthropogenic emissions (e.g. $\mathrm{NO}_{\mathrm{x}}$ and benzene); a biomass burning organic aerosol (BBOA) component; and two oxygenated organic aerosol components (OOA-1, OOA2 ), where OOA-1 is more oxygenated than OOA-2. OOA-1 correlates with tracers for long-range transport (e.g. particulate sulphate), while OOA-2 correlates with VOCs measured by the PTR-MS at $m / z, 71$ (ion $\mathrm{C}_{4} \mathrm{H}_{6} \mathrm{OH}^{+}$) which is thought to arise from products of photochemistry (e.g. methacrolein and methyl vinyl ketone). Further detailed discussion about the PMF solutions can be found in Slowik et al. (2010), which also discusses that although the OOA-1 and OOA2 factor mass spectra are similar to those of low-volatility OOA (LV-OOA) and semivolatile OOA (SV-OOA), respectively (Jimenez et al., 2009), tracer correlations suggest that the Egbert time series are not necessarily driven by volatility. As such, we continue to use the more general OOA-1/OOA2 terminology, which allows the paper to remain consistent with the other publications from this study. However, after each mention of these factors we put in brackets the new terminology that is being used in the community, e.g. OOA-1 (LV-OOA). The important point for the current analysis is the differentiation between the oxygenated (OOA and BBOA) and unoxygenated (HOA) components of the organic aerosol.

A high-resolution time-of-flight AMS (HR-ToF AMS, Aerodyne) was also deployed at the site. The mass resolution of the HR-ToF AMS, (3000-5000), allows for fragments of nominally the same $\mathrm{m} / \mathrm{z}$ to be quantified separately, and hence the total molar ratio of oxygen to carbon $(\mathrm{O} / \mathrm{C})$ can be determined. The application, accuracy, precision and limitations of the HR-ToF AMS in quantifying total $\mathrm{C}$ and O have been discussed previously (Aiken et al., 2007, 2008). Although the absolute accuracy of determining O/C for ambient aerosols using an AMS is not well established, it can be used as a tracer for atmospheric oxidation. High resolution data analysis for this study was completed using a custom algorithm, which incorporated a peak fitting procedure, typical AMS correction factors and a correction for the $\mathrm{O} / \mathrm{C}$ as suggested by Aiken et al. (2008) to account for discrepancies between AMS derived $\mathrm{O} / \mathrm{C}$ and that derived from laboratory standards. While the subsequent calculations and results are from the C-ToF AMS, they will be compared with O/C results from the HR-ToF AMS in Sect. 4.1.2.

\section{Methodology for determining the hygroscopicity parameter}

\subsection{Determining the hygroscopicity of the organic component}

Data were averaged into $15 \mathrm{~min}$ intervals. Using the chemical composition measured by the C-ToF AMS, the activation diameter for a dry particle at the supersaturation of the CCN chamber $(0.42 \%)$ was calculated using $\kappa$-Köhler theory (Petters and Kreidenweis, 2007, 2008), which simplifies the Köhler equation to

$S=\frac{D^{3}-D_{\mathrm{i}}^{3}}{D^{3}-D_{\mathrm{i}}^{3}(1-\kappa)} \exp \left(\frac{4 \sigma M_{\mathrm{w}}}{\rho_{\mathrm{w}} \mathrm{RTD}}\right)$,

where $D$ and $D_{\mathrm{i}}$ are the droplet wet diameter and initial dry diameter, respectively, $\sigma$ is the droplet surface tension (assumed to be that of water, $0.072 \mathrm{~N} \mathrm{~m}^{-2}$ ), $M_{\mathrm{w}}$ is the molecular weight of water, $\rho_{\mathrm{w}}$ is the density of water, $R$ is the universal gas constant, $T$ is the temperature, and $\kappa$ is a $\sin$ gle parameter that combines all the compound-specific variables (e.g. molecular weight, density, van't Hoff factor) of the aerosol.

In this equation, the overall $\kappa$ of the aerosol is calculated as the volume-weighted average of the $\kappa$ of the components, which assumes that the total volume of the water content can 
be calculated by adding the water contents of the individual components (Petters and Kreidenweis, 2007), i.e.

$\kappa=\sum_{i} \varepsilon_{i} \kappa_{i}$

where $\varepsilon_{i}$ and $\kappa_{i}$ are the volume fraction and $\kappa$ of the $i^{\text {th }}$ components of the aerosol. For a soluble compound, $\kappa_{i}$ can theoretically be expressed as:

$\kappa_{i}=\frac{i_{i} \rho_{i} M_{\mathrm{w}}}{\rho_{\mathrm{w}} M_{i}}$,

where $i_{i}, \rho_{i}$, and $M_{i}$ are the van't Hoff factor, density and molecular weight, respectively, of the compound. In practise, however, $\kappa$ for a well-characterised compound such as ammonium sulphate can be inferred by using water activity data (e.g. Clegg et al., 1996) to calculate a Köhler curve, and then recreating this curve using Eq. (1) and adjusting $\kappa$ until it has the same critical supersaturation as that calculated from the water activity data. In this way, $\kappa$ for ammonium sulphate and ammonium nitrate at $0.42 \%$ were determined to be 0.59 and 0.72 , respectively (Clegg et al., 1996, 1998; Wexler and Clegg, 2002).

The inorganics measured by the AMS, ammonium, nitrate and sulphate, were grouped together and assumed to behave as ammonium sulphate, with a $\kappa$ of 0.59 and density of $1770 \mathrm{~kg} \mathrm{~m}^{-3}$ (Windholz, 1983) so that Eq. (2) can be written as

$\kappa_{\mathrm{tot}}=\varepsilon_{\text {inorg }} \cdot \kappa_{\text {inorg }}+\varepsilon_{\mathrm{org}} \cdot \kappa_{\mathrm{org}}$,

where inorg and org represent the inorganic and organic components measured by the AMS, respectively. The errors associated with this assumption are not large (see Sect. 4.3) since the aerosol was not acidic during the study and the $\kappa$ and density of ammonium nitrate are 0.72 and $1730 \mathrm{~kg} \mathrm{~m}^{-3}$ (Windholz, 1983), respectively, which are close to the values for ammonium sulphate. The sensitivity of our results to the presence of black carbon is discussed in Sect. 4.3 and the contribution of mineral dust to the aerosol submicron fraction is considered negligible at this site.

There are numerous approaches in representing $\kappa_{\text {org }}$. However, in this analysis we will focus on two methods, both of which are based on the degree of oxygenation of the organic component as determined from AMS measurements. We generally assume that a more oxygenated organic aerosol is more polar and therefore more soluble and hygroscopic than a less oxygenated organic aerosol. In contrast, the more hydrocarbon-like component of the aerosol is non-polar and therefore less hygroscopic. We justify these assumptions in depth in Sect. 3.3. Under these assumptions, there is the expectation that the aerosol's hygroscopicity will increase with the degree of oxygenation, although this relationship would intrinsically arise from factors such as molecular weight or solubility, that would affect hygroscopicity and be related to the oxygenation of the organic components.
The first approach to representing $\kappa$ uses the factors from the PMF analysis grouped into two components: a non-hygroscopic, unoxygenated component consisting of the HOA factor, whose $\kappa$ ( $\left.\kappa_{\text {unox }}\right)$ is approximated by 0 , and a hygroscopic component, consisting of the oxygenated factors OOA-1 (LV-OOA), OOA-2 (SV-OOA) and BBOA with a $\kappa$ of $\kappa_{\mathrm{ox}}$ such that $\kappa_{\text {org }}$ in Eq. (4) can be expressed as:

$\kappa_{\mathrm{org}}=\varepsilon_{\mathrm{ox}} \cdot \kappa_{\mathrm{ox}}+\varepsilon_{\mathrm{unox}} \cdot \kappa_{\mathrm{unox}}=\varepsilon_{\mathrm{ox}} \cdot \kappa_{\mathrm{ox}}$,

where the density for the organic component used to calculate the volume fractions in both Eq. (4) and Eq. (5) are $1500 \mathrm{~kg} \mathrm{~m}^{-3}$ (Kostenidou et al., 2007) for the oxygenated organic components, thought to be similar to SOA, and 900 $\mathrm{kg} \mathrm{m}^{-3}$ (Cylinder Lube 1000) for the unoxygenated organic component, thought to be composed of lubricating oil-like compounds (Zhang et al., 2005a). Note that $\varepsilon_{\text {ox }}$ in Eq. (5) refers to the volume fraction of the oxygenated component in relation to the organic component only. Since $\kappa_{\mathrm{Ox}}$ is the only parameter that is not measured, it can be varied until the ratio of predicted to measured $\mathrm{CCN}$ number concentrations $\left(R_{\mathrm{CCN}}\right)$ is internally consistent (as described in Sect. 3.2). The oxygenated factors were grouped together because our model was not sensitive enough and/or our measurements were not accurate enough to elucidate separate hygroscopicities for each factor.

The second approach assumes a direct relationship between the organic aerosol's degree of oxygenation and its hygroscopicity. The simplest relationship is a linear one, so that

$\kappa_{\mathrm{org}}=a \cdot(\mathrm{O} / \mathrm{C})$,

where $\mathrm{O} / \mathrm{C}$, the mole ratio of atomic oxygen to atomic carbon, is a measurement of the organic aerosol's degree of oxygenation and can be estimated from the fraction of the total organic signal occurring at $\mathrm{m} / \mathrm{z}, 44$ measured by the CToF AMS using the equation in Fig. $4 \mathrm{~b}$ of Aiken et al. (2008). In Eq. (6), $a$ is the sensitivity of $\kappa_{\text {org }}$ on $\mathrm{O} / \mathrm{C}$ and is unknown, allowing it to be varied until $R_{\mathrm{CCN}}$ is again internally consistent. We stress that this postulated relationship between the organic aerosol's $\mathrm{O} / \mathrm{C}$ and hygroscopicity may not be linear and more complicated relationships between the two quantities will exist that may be more accurate, but for the purposes of this study, we start with the simplest functionality.

Using either approach, $\kappa$ for the entire aerosol can be calculated from Eq. (4) combined with either Eq. (5) or Eq. (6). The initial particle size $\left(D_{\mathrm{i}}\right)$ in Eq. (1) was increased until the critical supersaturation was equal to the supersaturation of the $\mathrm{CCN}$ counter $(0.42 \%)$ to determine the critical diameter. The aerosol size distribution, as measured by the SMPS, was then integrated for all dry particle sizes greater than the activation diameter to arrive at the predicted $\mathrm{CCN}$ concentration. $\kappa_{\mathrm{org}}$ was then iteratively varied (either by changing $\kappa_{\mathrm{ox}}$ in Eq. 5 or $a$ in Eq. 6), changing the activation diameter and thus predicted CCN concentration, until $R_{\mathrm{CCN}}$ was internally consistent, as will be described in the next section. 


\subsection{Statistical methods}

The relative contribution of the organic component to the hygroscopicity of the ambient aerosol at Egbert depends on the magnitude of the inorganic fraction (Chang et al., 2007), with the organic fraction contributing less to a particle's overall hygroscopicity in inorganic-rich particles. In addition, since the hygroscopicity of inorganic particles has been studied extensively, it is expected that the predicted CCN concentrations during periods in which the aerosol is mostly inorganic would be more accurate. A plot of $R_{\mathrm{CCN}}$, the ratio of $\mathrm{CCN}$ concentrations predicted using the $\kappa$-Köhler model to concentrations measured with the $\mathrm{CCN}$ counter, for the entire study is plotted as a function of aerosol inorganic fraction in Fig. 1a (consider all data points in the figure). Figure 1a shows that $R_{\mathrm{CCN}}$ is dependent on composition when the entire organic component is assumed to be non-hygroscopic (i.e. $\kappa_{\mathrm{org}}=0$ ), with the organic-rich data points, the lower 50th percentile of the entire population in Fig. 1a, being underpredicted $\left(R_{\mathrm{CCN}}=0.871 \pm 0.007\right)$ compared to the inorganic-rich data points, the upper 50th percentile of the entire population in Fig. 1a, which averaged to $1.17 \pm 0.01$. Note that the average $R_{\mathrm{CCN}}$ over all chemical compositions is $0.974 \pm 0.006$. As the distributions were log-normal, the values given are the geometric mean and the uncertainties are the standard error, calculated based on the geometric standard deviation, although these values do not vary greatly from the linear statistics $\left(R_{\mathrm{CCN}}=0.902 \pm 0.007\right.$ and $R_{\mathrm{CCN}}=1.15 \pm 0.01$ for the organic-rich and inorganic-rich halves of the population, respectively).

In order to assess this systematically, the data points were sorted based on the magnitude of their inorganic fraction and the mean $R_{\mathrm{CCN}}$ of the upper and lower 50th percentiles were then compared. $\kappa_{\text {org }}$ for the entire data set was varied until the means of the two halves were no longer significantly different (two-tailed t-test, unequal variances, significance level of $p<0.05$ ). Since aerosols with a high inorganic fraction are less sensitive to changes in the hygroscopicity of the aerosol's organic component (see Broekhuizen et al., 2006; Chang et al., 2007), the mean of the more inorganic half of the population was used as a reference.

This method of internal comparison was chosen because both measured and predicted CCN concentrations are precise but not necessarily fully accurate due to experimental uncertainties, such as different line losses to the SMPS and $\mathrm{CCN}$ counter, errors in the sizing of the SMPS and counting errors in both systems, as well as uncertainties in model assumptions, such as mixing state, particle sphericity, density, etc. As such, the criterion for the best value of $\kappa_{\mathrm{ox}}$ is a consistent $R_{\mathrm{CCN}}$, whether over- or underpredicted, regardless of composition. However, this method is susceptible to any systematic errors that may selectively affect either the inorganic or organic components measured by the AMS. These uncertainties are considered in Sect. 4.3.

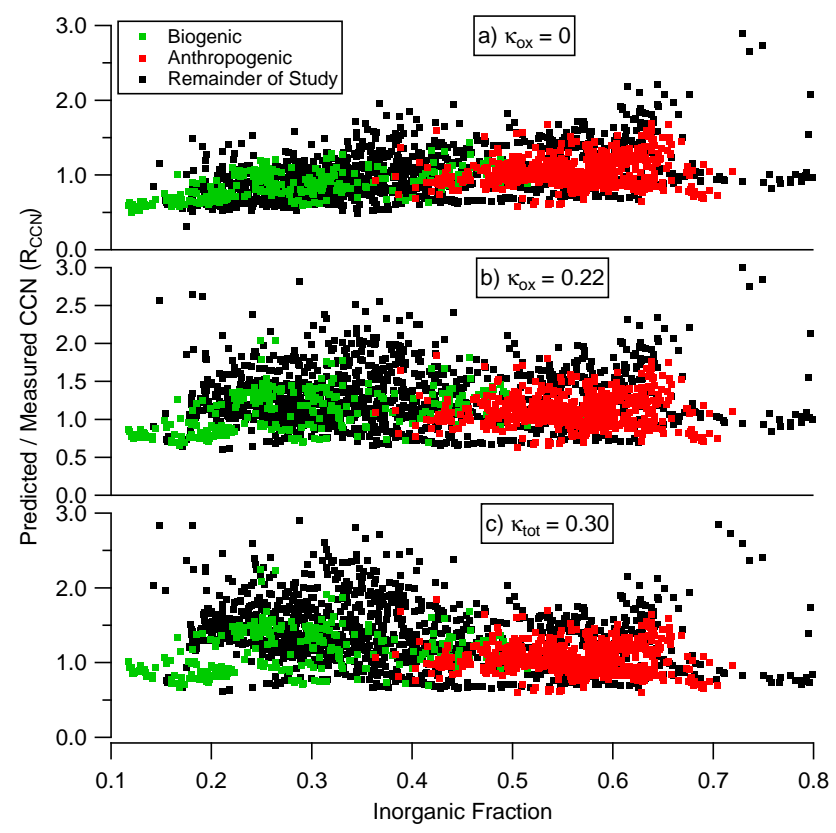

Fig. 1. Ratio of predicted to measured $\mathrm{CCN}$ concentrations plotted against aerosol inorganic fraction. Panel (a) shows the case in which all of the organic component is assumed to be non-hygroscopic $\left(\kappa_{\mathrm{org}}=0\right)$ while (b) shows the case in which $\kappa_{\mathrm{ox}}=0.22$. Panel (c) assumes a constant $\kappa$ of 0.30 for the entire aerosol. Red and green points refer to data from the Anthropogenic and Biogenic periods, respectively (see Fig. 3), while the remainder of the study is represented by black points.

\subsection{Degree of oxygenation and hygroscopicity: assumptions and approach}

It should be noted that our goal in this work is to extend previous studies by working from an assumption that has been used in the past, i.e. that some part of the organic aerosol component leads to $\mathrm{CCN}$-activity and another does not. Whereas past aerosol-CCN closure studies have only assumed that a constant fraction of the organic aerosol component is soluble and that the remainder is insoluble (Broekhuizen et al., 2006; Chang et al., 2007; Medina et al., 2007; Stroud et al., 2007), in this paper we suggest that the oxygenated factors from the PMF analysis represent the soluble organic component while the unoxygenated factor represents the insoluble organic component. Or, using the concept of hygroscopicity, we postulate that the oxygenated factors contribute to the hygroscopicity of the aerosol, and that the unoxygenated factor does not, whether due to its solubility, as suggested by Petters et al. (2009b), or its intrinsic hygroscopicity.

Although extraction of the $\kappa$ of both the oxygenated and unoxygenated components from an unconstrained fit of the data to a model would be the ideal approach, the uncertainties in our measurements were too large to evaluate the difference between sets of $\kappa$ parameters. In part, this is because 
of the relatively narrow range of oxygenation observable at one field site during one campaign. And so, we constrained our model by assuming that the unoxygenated (HOA) component of the organic aerosol contributed minimally to the aerosol hygroscopicity. This is not unreasonable because HOA is thought to be hydrocarbon-like (Zhang et al., 2005a) and aliphatic in nature, and in general, these types of compounds have not been found to be $\mathrm{CCN}$-active in laboratory experiments (e.g. Pradeep Kumar et al., 2003; Raymond and Pandis, 2002). In addition, ambient measurements of particles at locations in which HOA is high, especially at the smaller sizes, have shown that the organic component does not appear to contribute to the $\mathrm{CCN}$-activity (Cubison et al., 2008; Quinn et al., 2008; Broekhuizen et al., 2006). Based on these literature results, we feel that the assumption that the unoxygenated component is non-hygroscopic is reasonable.

In contrast to the HOA factor, the OOA factors, which make up most of the oxygenated component of the organic aerosol, are thought to be characteristic of highly processed organic aerosols (Zhang et al., 2005a) formed from secondary processes (Zhang et al., 2007). Again, laboratory experiments of compounds that are formed from these types of processes such as glutamic, glutaric, pinonic and norpinic acids have found that these aerosols are moderately CCNactive (Raymond and Pandis, 2002) and smog chamber studies of gaseous organic precursors with ozone or $\mathrm{OH}$ have also found that the organic aerosols formed are moderately $\mathrm{CCN}$ active (e.g. Duplissy et al., 2008). In addition, this assumption is supported by laboratory studies that have found that oleic acid particles that have undergone ozonolysis become somewhat CCN-active (Broekhuizen et al., 2004b; Shilling et al., 2007) and chamber studies that show that ageing organic aerosols can also increase their $\mathrm{CCN}$-activity to varying amounts (Duplissy et al., 2008; Petters et al., 2006; Wex et al., 2009). We do note that there is also some evidence that the hygroscopicity of SOA under supersaturated conditions in chamber studies do not vary with ageing (Jurányi et al., 2009; Prenni et al., 2007).

These findings lend credence to treating the oxygenated component of the organic aerosol as $\mathrm{CCN}$-active and that it is reasonable to assume that this factor dominates the overall organic aerosol hygroscopicity. Thus, the main objective of this work was to attempt to constrain the hygroscopicity of the oxygenated organic component of ambient aerosols.

The hygroscopicity of the BBOA component has uncertainty associated with it. Originally, we viewed the full BBOA factor to be similar to the biomass burning marker levoglucosan (see Lanz et al., 2007), which is quite hygroscopic (Petters and Kreidenweis, 2007) and was therefore grouped with OOA in the oxygenated component. However, more recent work has suggested that there are other components that make up the BBOA fraction (Petters et al., 2009a) that are not as hygroscopic, which is why its solubility is considered in Sect. 4.3.
Table 1. O/C calculated for the PMF factors of the organic aerosol component.

\begin{tabular}{llr}
\hline Factor & $m / z$ 44/Total Organic & $\mathrm{O} / \mathrm{C}$ \\
\hline OOA-1 (LV-OOA) & 0.19 & 0.81 \\
OOA-2 (SV-OOA) & 0.10 & 0.46 \\
BBOA & 0.025 & 0.17 \\
HOA & $8 \times 10^{-8}$ & $<0.08$ \\
\hline
\end{tabular}

The reasoning behind the postulated relationship between $\kappa_{\text {org }}$ and $\mathrm{O} / \mathrm{C}$ is similar to that above. Since PMF finds factors by reconstructing the organic mass spectrum as linear combinations of these factors, the $\mathrm{O} / \mathrm{C}$ of the organic component (since it is based on the signal at $\mathrm{m} / \mathrm{z} 44$ ) can also be calculated as a linear combination of the $\mathrm{O} / \mathrm{C}$ of our factors, with the $\mathrm{O} / \mathrm{C}$ of the unoxygenated component approaching zero and the $\mathrm{O} / \mathrm{C}$ of the most oxygenated component at 0.81 (see Table 1). Organic aerosols with mixed compositions will lie between these two values. Mathematically, both Eq. (5) and Eq. (6) can be considered for an organic component that is composed entirely of the oxygenated factors, resulting in a $\kappa_{\mathrm{org}}$ of $\kappa_{\mathrm{ox}}$ or $a \cdot(\mathrm{O} / \mathrm{C}$ of the oxygenated component), while a completely unoxygenated organic aerosol would have $\kappa_{\text {org }}=0$ using either equation (since the O/C of the unoxygenated (HOA) component approaches 0 ). In reality, these two methods are not exactly the same since the factor method uses the volume-weighted average while the $\mathrm{O} / \mathrm{C}$ method uses mass-weighted averages, which result in a slightly different shape to the curves. However, for the most part, these two methods essentially represent the same relationship between the degree of oxygenation of the aerosol and its hygroscopicity.

Results from laboratory studies are inconclusive about the relationship between organic oxygenation and hygroscopicity under supersaturated conditions. Unoxygenated organic aerosols that are non-hygroscopic such as oleic acid, stearic acid and bis-2-ethylhexyl sebacate, can be heterogeneously oxidised such that they become moderately hygroscopic (Broekhuizen et al., 2004b; George et al., 2009; Petters et al., 2006; Shilling et al., 2007). A smog chamber study by Wex et al. (2009) also showed that the hygroscopicity of SOA increased in the absence of an $\mathrm{OH}$ scavenger, which the authors suggested was due to increased oxidation in the organic aerosol. Finally, Duplissy et al. (2008) also showed that the hygroscopicity increased slightly throughout the photoxidation of $\alpha$-pinene. However, there have also been several studies of SOA in smog chambers that have not observed any dependence of hygroscopicity on degree of oxygenation, whether by varying precursor concentrations that should result in varying oxygenation in the final aerosol (Jurányi et al., 2009), or by monitoring the hygroscopicity throughout a reaction (Prenni et al., 2007). As such, the 
dependence of hygroscopicity on the degree of oxygenation from laboratory studies is unclear. However, the applicability of these lab experiments to ambient conditions has not been fully confirmed, given that chamber-generated SOA tend to be less oxygenated than the OOA-1 (LV-OOA) component found in highly processed ambient aerosols ( $\mathrm{Ng}$ et al., 2010). Although the focus of this work is on supersaturated conditions, and it is unclear whether such $\kappa$ parameters are fully the same as those derived from subsaturated conditions, we do note that $\kappa$ for organic aerosols measured under subsaturated conditions have recently been reported to scale with the $\mathrm{O} / \mathrm{C}$ of the aerosol (Jimenez et al., 2009).

\section{Results and discussion}

\subsection{Results from the entire study}

\subsubsection{Calculations using oxygenated and unoxygenated factors}

Using the method described in Sect. 3.2 and Eq. (5), $\kappa_{\mathrm{ox}}$ for the entire study was found to be $0.22 \pm 0.04$. Figure $1 \mathrm{~b}$ shows that increasing the hygroscopicity of the organic component reduces the difference between the mean $R_{\mathrm{CCN}}$ of the organic-rich data points and the inorganic-rich data points (geometric mean $R_{\mathrm{CCN}}$ are $1.19 \pm 0.02$ and $1.18 \pm 0.01$, respectively), compared to the completely non-hygroscopic case (Fig. 1a). It is difficult to reconcile the overprediction from this calculation of almost $20 \%$ to that calculated from a linear regression of the predicted and measured $\mathrm{CCN}$ concentrations, which resulted in a slope of 1.03 (see Fig. 2). While the slope from the linear regression is comparable to other field studies (Broekhuizen et al., 2006; Chang et al., 2007; Medina et al., 2007; Wang et al., 2008) which have found similar values, it is calculated in a different way and puts more emphasis on the data points at high concentrations. In an attempt to lessen this effect, a linear regression of the logarithm of the concentrations was also attempted, although this resulted in a similar slope of 1.02. Finally, if the data points are weighted by their estimated error $( \pm 20 \%$ for measured $\mathrm{CCN}$ concentrations) and the intercept forced through zero, then the slope can be increased to 1.10 (1.05 if the intercept is not forced through zero), which halves the discrepancy with the value obtained from $R_{\mathrm{CCN}}$. Nevertheless, this difference is within the uncertainties of our $\mathrm{CCN}$ counter.

\subsubsection{Calculations using $\mathrm{O} / \mathrm{C}$}

Using the $\mathrm{O} / \mathrm{C}$ to calculate $\kappa_{\text {org }}$ from Eq. (6), and varying $a$ in the method described in Sect. 3.2 resulted in the relationship

$\kappa_{\text {org }}=(0.29 \pm 0.05) \cdot(\mathrm{O} / \mathrm{C}),(0.3<\mathrm{O} / \mathrm{C}<0.6)$,

where the uncertainties are values for which the means of the two halves of the population are not significantly different (two-tailed t-test, unequal variances, significance level of

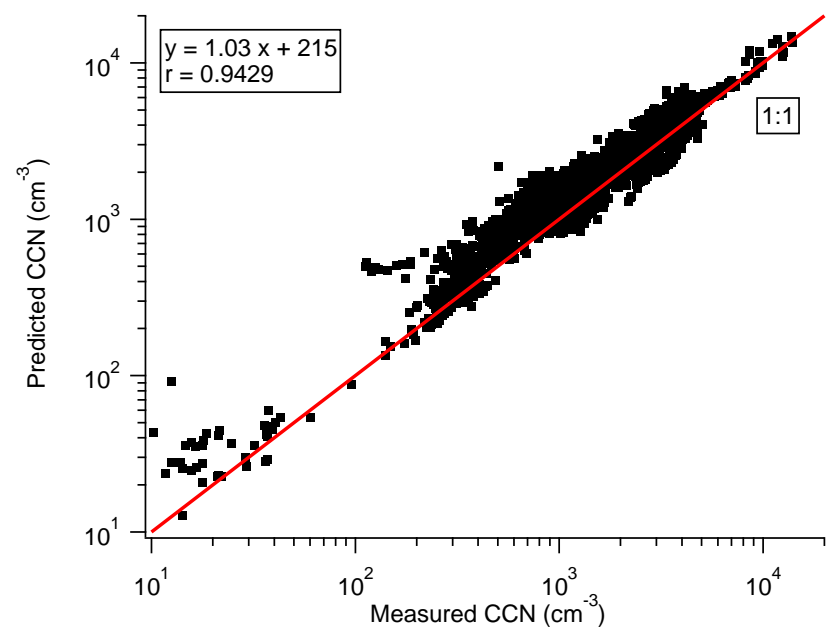

Fig. 2. Comparing predicted and measured $\mathrm{CCN}$ concentrations for the entire study assuming that $\kappa_{\mathrm{OX}}=0.22$. The red line is the $1: 1$ line.

$p<0.05$ ) and the range of $\mathrm{O} / \mathrm{C}$ observed during this study and used to derive this relationship was 0.3 to 0.6. As mentioned previously, the $\mathrm{O} / \mathrm{C}$ was estimated from the fraction of the organic signal at $m / z 44$, directly from the C-ToF AMS mass spectra, which, on average, is $6 \%$ higher than that calculated from the HR-ToF AMS. The grey trace in the top panel of Fig. 3 shows the time series for $\kappa_{\text {org }}$ calculated using the PMF factors, assuming $\kappa_{\mathrm{ox}}=0.22$ and $\kappa_{\mathrm{unox}}=0$, while the black and red traces are from Eq. (7), using $\mathrm{O} / \mathrm{C}$ estimated from the $\mathrm{C}$ ToF and HR-ToF AMSs, respectively. We see that all three estimates of $\kappa_{\text {org }}$ yield similar results. This is not unexpected since both the PMF and O/C approaches incorporate the degree of oxygenation of the organic component calculated using different analyses. In essence, this shows that the O/C of the entire aerosol can be reasonably expressed as a linear combination of the $\mathrm{O} / \mathrm{C}$ of the PMF factors.

The attraction of this method is that $\kappa_{\text {org }}$ is calculated from the degree of oxygenation of the organic component of the aerosol as deduced from aerosol mass spectra and does not depend on PMF, which involves a stage of statistical analysis. However, it is unclear whether this approach can be generalised to other aerosol types and locations because the range in the $\mathrm{O} / \mathrm{C}$ for this study was quite limited $(0.3$ to 0.6$)$. As such, analysis of ambient aerosols with a wider range of oxygenation should be tested to determine whether this simple relationship between hygroscopicity and aerosol oxygenation is widely applicable.

As a general caveat, the slope in Eq. (7) may only be representative of the conditions in this study, which examine the bulk ambient, non-refractory organic aerosols measured specifically by the AMS. Also, it does not account for organonitrate or organosulphate components that may be present. Not only do these compounds contribute to an underestimation of the actual O/C (Farmer et al., 2010), but they are also oxygenated and likely hygroscopic, without 


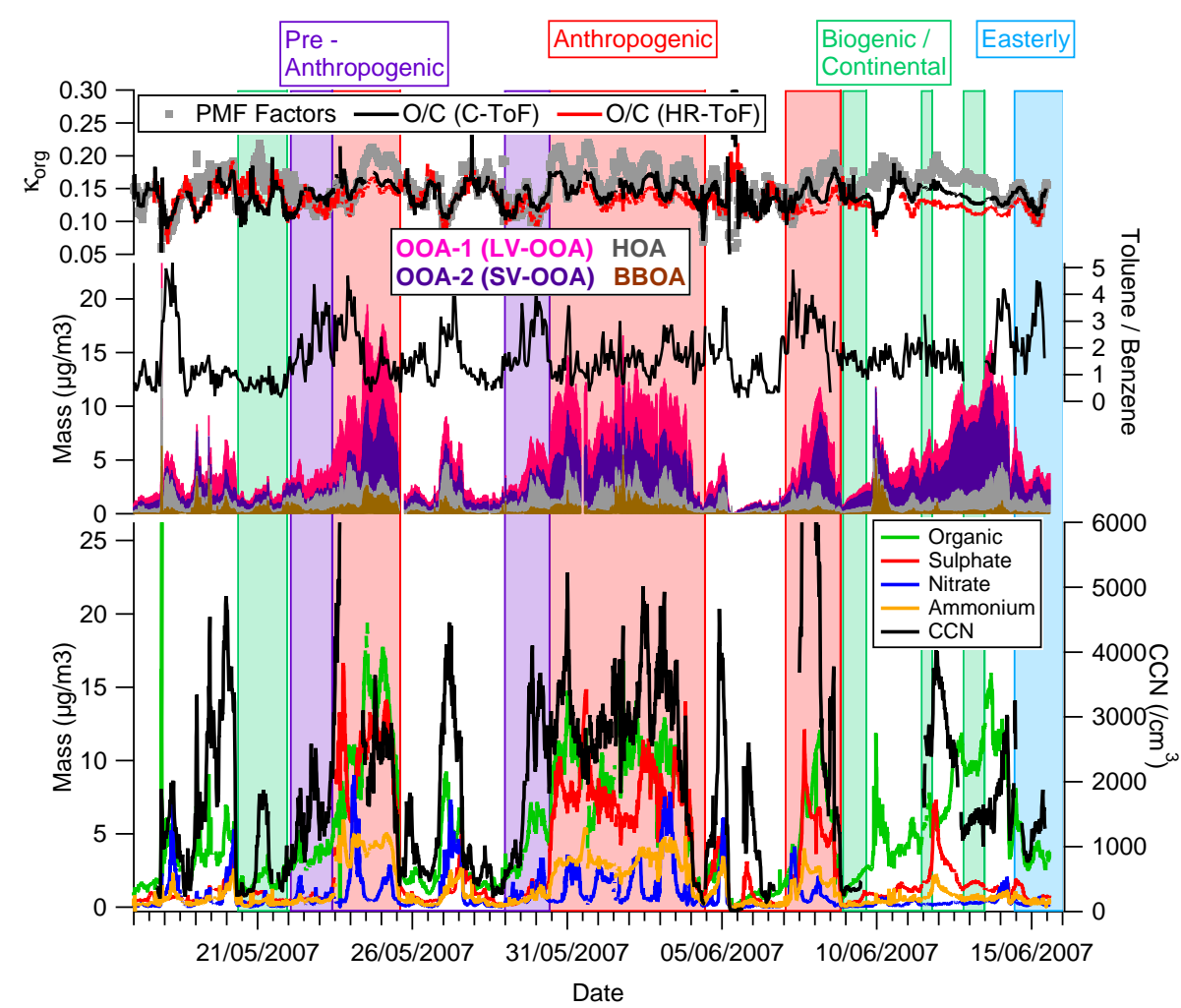

Fig. 3. Time series in local time of $\kappa_{\text {org }}$ calculated from PMF factors and O/C (top panel, see text for more detail), toluene/benzene (black trace in middle panel), PMF factors (middle panel, note that these are cumulative), and aerosol chemical measurements measured by the AMS and CCN concentrations (bottom panel).

contributing to the $\mathrm{O} / \mathrm{C}$ itself, further underestimating the organic component's hygroscopicity. It is important to note that a relationship between $\mathrm{O} / \mathrm{C}$ and $\kappa_{\text {org }}$ would not necessarily indicate that the former controls the latter. Rather, it would suggest that $\mathrm{O} / \mathrm{C}$ correlates to molecular properties that affect an organic particle's hygroscopicity, such as molecular weight and solubility. Nonetheless, we feel that this relationship may provide useful insight since $\mathrm{O} / \mathrm{C}$ can be derived directly from mass spectral data.

Similar to the method described by Shinozuka et al. (2009), it is possible to directly infer $\kappa$ for the organic component of the aerosol. The activation diameter is first determined by finding the diameter above which the aerosol size distribution would equal the measured CCN concentrations. Using the activation diameter and the supersaturation of the chamber, $\kappa$ for the entire aerosol can be determined and $\kappa_{\text {org }}$ calculated from Eq. (4). These values are plotted against the $\mathrm{O} / \mathrm{C}$ in black in Fig. 4. In this figure, the grey lines are the uncertainties in $\kappa_{\text {org }}$ calculated based on the $\pm 20 \%$ uncertainty in the measured $\mathrm{CCN}$ concentration and the blue line is the relationship postulated in this analysis. Further, following the method described by Shinozuka et al. (2009), these values were binned by $\mathrm{O} / \mathrm{C}$ in increments of 0.025 , as shown by the red points in Fig. 4 , although only $\kappa_{\text {org }}<5$ were considered in this analysis. These results do not change significantly if the geometric mean for each bin is used instead of the presented arithmetic mean. The uncertainties in these binned data were determined by adding in quadrature the standard error to the error calculated from error propagation of the uncertainties in the inferred $\kappa_{\text {org }}$. The uncertainties in the $\mathrm{O} / \mathrm{C}$ have not been included in the figure to maintain clarity, however, they are approximately \pm 0.1 as determined from Aiken et al. (2008).

The binned $\kappa_{\text {org }}$ have high uncertainties associated with them. To derive an empirical relationship, we note that the unweighted least-squares-fit indeed indicates a positive correlation between $\kappa_{\text {org }}$ and $\mathrm{O} / \mathrm{C}$ $\left(\kappa_{\text {org }}=(0.9 \pm 0.5) \cdot(\mathrm{O} / \mathrm{C})-(0.3 \pm 0.2), \quad 0.3<\mathrm{O} / \mathrm{C}<0.6\right), \quad$ although the uncertainties in the fit parameters are very high. It is for this reason that we chose to constrain our data by assuming that the unoxygenated component of the aerosol is completely non-hygroscopic, thus focusing our analysis on extraction of only one parameter, (i.e. either the $\kappa_{\mathrm{Ox}}$ or the slope of the $\kappa_{\text {org }}$ vs. O/C linear relationship). If the empirical relationship in Fig. 4 between $\kappa_{\text {org }}$ and $\mathrm{O} / \mathrm{C}$ is valid, then it suggests that inclusion of a negative intercept may be more appropriate in Eq. (6). However, we do not feel comfortable making that conclusion based on our data alone, given the high uncertainties. 


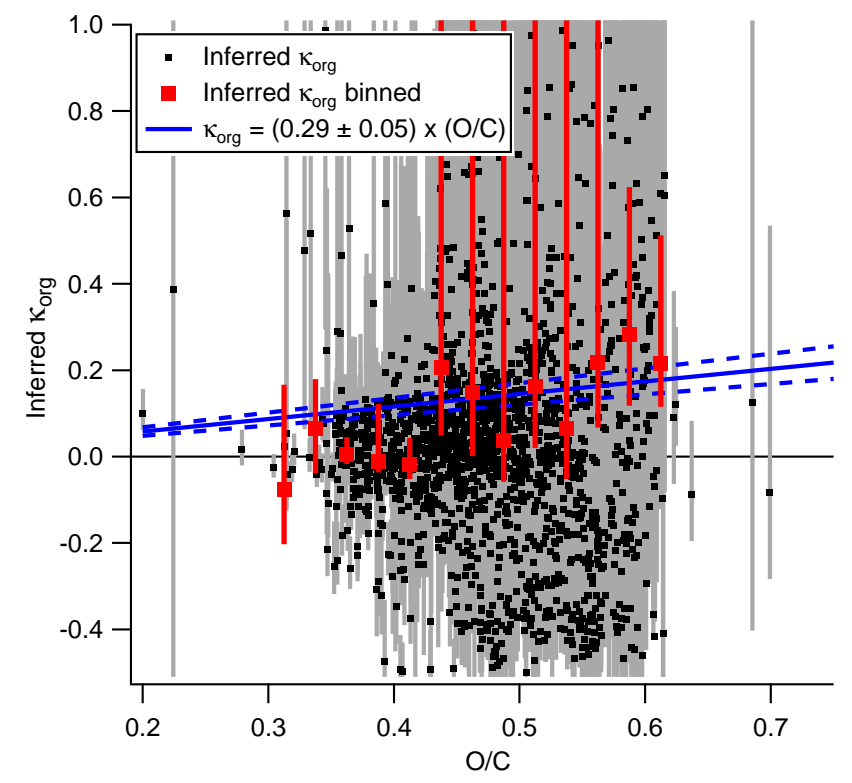

Fig. 4. $\kappa_{\text {org }}$ inferred from size distributions as a function of $\mathrm{O} / \mathrm{C}$. Grey lines are the uncertainties in the inferred $\kappa_{\text {org }}$. Red points are data binned by 0.025 . The uncertainties in the $\mathrm{O} / \mathrm{C}$ for the binned data points are \pm 0.1 . See text for more detail.

These results appear to be similar to those published by Jimenez et al. (2009), despite the fact that their measurements were made at subsaturated conditions and numerous studies have found that hygroscopicity of chamber-generated SOA at subsaturated regimes appears to be more dependent on the organic aerosol's degree of oxygenation than at supersaturated regimes (e.g. Jurányi et al., 2009; Petters et al., 2009b; Prenni et al., 2007). However, as stated above, we do not feel that our data sufficiently constrain the $\kappa_{\text {org }}$ vs. O/C relationship.

\subsection{Results from select time periods using oxygenated and unoxygenated factors}

Because local sources were not prominent at the sampling site, it was possible to characterise regional air masses during which the organic aerosol composition was assumed to be more uniform. From this analysis, we can assess the degree to which the organic components have the same hygroscopicity regardless of source by seeing how consistent these results are with the results from Sect. 4.1 for the entire study. The study was broken down into four air regimes based on aerosol chemical composition, the characteristics of the organic component (based on the PMF factors), local wind direction and wind speed, the photochemical age of the air from the ratio of toluene to benzene (de Gouw et al., 2005; Roberts et al., 1984), and back trajectories. The four air regimes are described below and illustrated in Fig. 3 with typical back trajectories calculated using HYSPLIT (Draxler

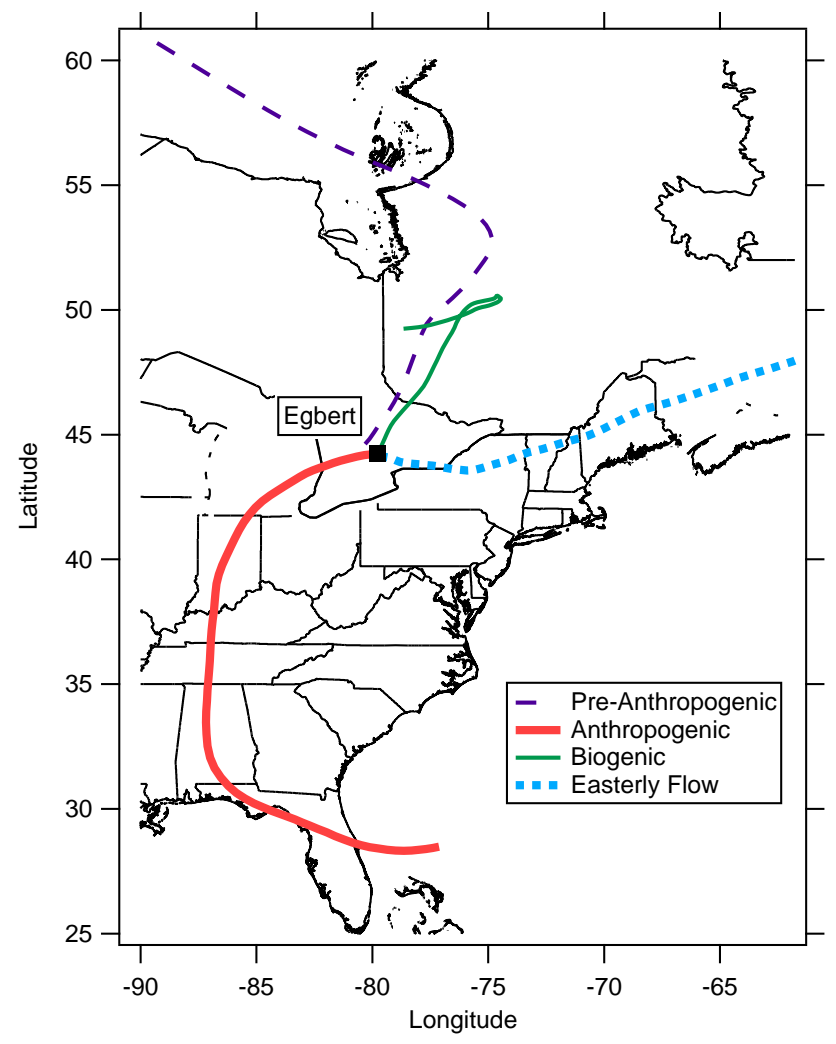

Fig. 5. $72 \mathrm{~h}$ back trajectories for 22 May 2007 (Pre-Anthropogenic), 2 June 2007 (Anthropogenic), 13 June 2007 (Biogenic) and 15 June 2007 (Easterly Flow). Trajectories were produced using NOAA HYSPLIT (Draxler and Rolph, 2003; Rolph, 2003).

and Rolph, 2003; Rolph, 2003) shown in Fig. 5. All dates and times are local, eastern daylight savings time.

1. For this study, periods of high anthropogenic influence were characterised by both high sulphate and organic aerosol mass loading. The toluene/benzene was often high, suggesting a shorter photochemical age, and back trajectories show that the air masses originated from populated regions to the south (thick red trace in Fig. 5). These periods are referred to as "Anthropogenic", while recognizing that aerosol precursors will not be exclusively anthropogenic.

2. Two of the Anthropogenic periods were preceded by times when the local winds were from the southeast (not shown) and the aerosol was mostly organic (specifically high HOA and OOA-1 (LV-OOA) and very low OOA2 (SV-OOA), as opposed to the Anthropogenic period which had more OOA-2 (SV-OOA)) with very little sulphate. The back trajectories tended to be from the northwest to northeast, suggesting that these air masses did not originate from highly populated or polluted regions (dashed purple trace in Fig. 5). However, because the toluene/benzene was notably high (suggesting that the 
photochemical age was short), it would appear that the aerosols during these times were from clean continental air but were influenced by quite fresh, local anthropogenic emission (e.g. a highway $10 \mathrm{~km}$ to the east). These periods are referred to as "Pre-Anthropogenic".

3. Continental air, characterised by low sulphate loadings, low toluene/benzene (suggesting enhanced photochemical processing) and higher organic mass fractions, was associated with trajectories from the mostly forested north (thin green trace in Fig. 5). The earlier episode (19-21 May) was colder and expectedly less influenced by biogenic emissions whereas the episode near the end of the study (8-13 June) was characterised by warmer temperatures and high organic mass loadings mostly from biogenic sources (Slowik et al., 2010). These periods are referred to as "Biogenic" for this analysis. Measurements during the second biogenic period were interrupted by a failure in the $\mathrm{CCN}$ counter, as well as a period (11 June, 18:15-12 June, 18:30) during which the air was elevated in $\mathrm{SO}_{2}$ and particulate sulphate concentrations. The majority of the sulphur in the latter case is suspected to have originated from smelters in the Sudbury region based on the back trajectories (not shown); such an observation at Egbert is not uncommon (Rupakheti et al., 2005).

4. At the end of the study, after the final Biogenic period, the winds shifted from the north to the east and the air was characterised by a high toluene/benzene as well as a higher HOA fraction (compared to the Biogenic period). Back trajectories show the air originating from the east (dotted blue trace in Fig. 5), suggesting that it is different from the Biogenic period. This period will be referred to as "Easterly Flow".

The composition of the aerosol during the Anthropogenic periods was dominated by the inorganic fraction, and similar to the arguments made in Sect. 3.2, is expected to be less sensitive to changes in the hygroscopicity of the organic component (Chang et al., 2007). An analysis similar to that described in Sect. 3.2 was used to evaluate $\kappa_{\mathrm{ox}}$, but in this case, the mean $R_{\mathrm{CCN}}$ of the Anthropogenic periods was used as a reference and compared to the mean $R_{\mathrm{CCN}}$ of the other time periods to determine their $\kappa_{\mathrm{ox}}$. This is illustrated in Fig. 1, which shows that $R_{\mathrm{CCN}}$ for the Anthropogenic periods (in red) is mostly inorganic (and makes up the majority of the points that are highly inorganic) and is less sensitive to an increase in $\kappa_{\mathrm{ox}}$ compared to the Biogenic periods (in green). Table 2 shows $\kappa_{\text {ox }}$ found for the different air regimes and the uncertainties denote when the mean $R_{\mathrm{CCN}}$ of the time periods became significantly different from that of the Anthropogenic periods.

For the Biogenic and Easterly Flow periods, $\kappa_{\text {ox }}$ are similar, suggesting that the hygroscopicity of the organic component can be characterised in the same manner. They are also
Table 2. $\kappa_{\mathrm{OX}}$ for select air regimes.

\begin{tabular}{lc}
\hline Air Regime & $\kappa_{\mathrm{Ox}}$ \\
\hline Biogenic & $0.25 \pm 0.06$ \\
Easterly Flow & $0.29 \pm 0.03$ \\
Pre-Anthropogenic & $0.07 \pm 0.03$ \\
\hline
\end{tabular}

similar to the value of 0.22 that was found from the analysis for the entire study period in Sect. 4.1.1. However, the Pre-Anthropogenic periods had a lower $\kappa_{\text {ox }}$ than the rest of the study, suggesting that during this time, the oxygenated components are not contributing significantly to the hygroscopicity of the aerosol. At this point we can only suggest reasons why this behaviour was observed. In particular, noting that the HOA component of the aerosol is high and that the air mass may have experienced recent traffic emissions, it is possible that the HOA plays a role in suppressing $\mathrm{CCN}$ activity, perhaps through an effect on the mass accommodation coefficient for water uptake, similar to the observations by Shantz et al. (2010). However, this is only speculation and we have no firm evidence that this is the case during this air regime.

For all these cases, we stress that the extracted $\kappa$ values have been derived using the Anthropogenic case as a reference, under an assumption that the organics do not strongly affect the hygroscopicity for such inorganic-rich particles.

Figure 6 shows plots of predicted to measured CCN concentrations for the different air regimes assuming $\kappa_{\mathrm{OX}}=0$ (black points) and $\kappa_{\mathrm{ox}}=0.22$ (red points). As expected, we see that during the Anthropogenic time (Fig. 6a), the predicted $\mathrm{CCN}$ concentrations do not change significantly compared to the Biogenic and Easterly Flow times (Fig. 6c and d), as well as the Pre-Anthropogenic time, which is even overpredicted (Fig. 6b) when $\kappa_{\text {ox }}=0.22$.

\subsection{Uncertainties}

Table 3 shows the sensitivity of our results to different uncertainties, calculated by changing each parameter and adjusting $\kappa_{\mathrm{org}}$, as described in Sect. 3.2, and reporting the difference. Systematic uncertainties in the chamber supersaturation $( \pm 0.04 \%$ supersaturation, Case 1$)$ and SMPS diameter sizing ( $\pm 5 \%$, Case 2$)$ are quantified for both calculation methods in Table 3. However, because the statistical method used to evaluate $\kappa_{\mathrm{ox}}$ and $a$ compares the mean ratio of predicted to measured $\mathrm{CCN}$ concentrations, our results are not sensitive to systematic uncertainties in the total concentrations of either the SMPS or the CCN counter.

Other uncertainties pertain to the aerosol chemical composition and attempts to quantify uncertainties in the density of the unoxygenated and oxygenated components (Cases 3 and 4 , respectively), both of which affect the calculation of 


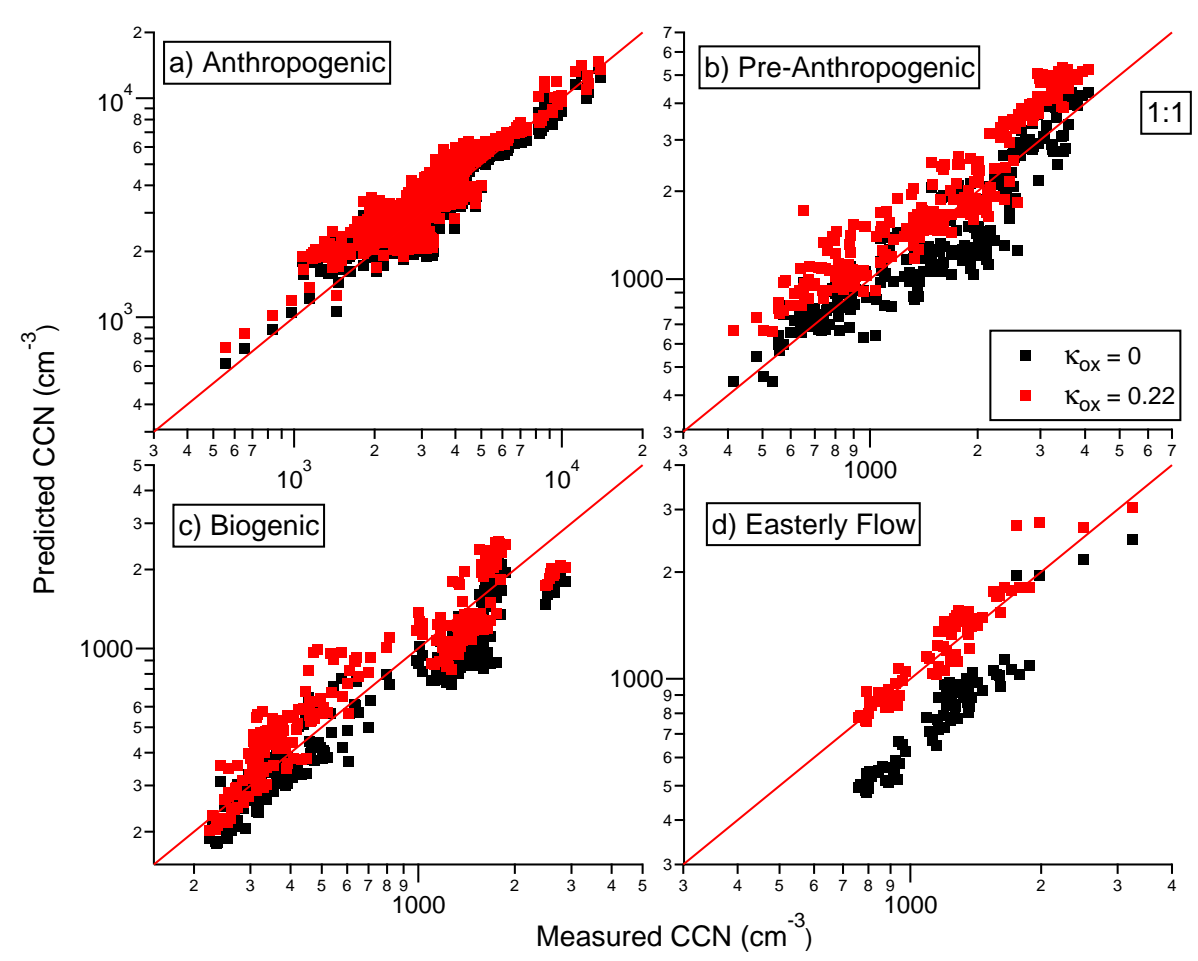

Fig. 6. Comparison of predicted and measured CCN concentrations for different time periods (see Fig. 3 ) with $\kappa_{\mathrm{OX}}=0$ (black) and 0.22 (red). The lines are 1:1 lines.

the volume fraction in Eq. (4) but appear to have minimal effect on $\kappa$. If the BBOA component is considered as nonhygroscopic (Case 5), the results for $\kappa_{\mathrm{ox}}$ are 0.04 higher. The uncertainties in determining the oxygenated and unoxygenated components can be large. Case 6 considers the case in which the mass fraction of the total organic that is oxygenated is increased by 0.1 (and the corresponding unoxygenated mass fraction decreases by 0.1) while Case 7 considers the effects if the opposite occurred. Similarly, Case 8 considers the effects of a $20 \%$ uncertainty in the $\mathrm{O} / \mathrm{C}$.

Results from Chan et al. (2010) for Egbert 2007 found that the ratio of elemental carbon to organic matter (EC/OM) for the study was 0.2 except for the final Biogenic periods, during which it decreased to 0.15 . Case 9 considers the normal case in which the ratio is 0.2 and the extra EC mass is assumed to be non-hygroscopic with a density of $1800 \mathrm{~kg} \mathrm{~m}^{-3}$. As mentioned in Sect. 3.1, the inorganics were grouped together in this analysis and assumed to behave as ammonium sulphate. Case 10 considers the change in $\kappa_{\mathrm{ox}}$ and $a$ if ammonium nitrate is calculated separately. The difference is not great, which is not surprising since its density and $\kappa$ are similar to that of ammonium sulphate.

The greatest uncertainty in the chemical composition of the aerosol arises from the degree to which the composition of the particles $<100 \mathrm{~nm}$ (i.e. the activation diameters typical of this study) is similar to the composition of the bulk aerosol. To this end, three cases are considered. Case 11 considers the changes in $\kappa_{\mathrm{ox}}$ and $a$ if the chemical composition is calculated from the size distribution data of the C-ToF AMS for vacuum aerodynamic diameters $80-250 \mathrm{~nm}$, as an indication of the composition of the smaller particles, while Case 12 and 13 consider the more general cases of the organic and inorganic components of the aerosol being 50\% greater at smaller sizes compared to the bulk aerosol, respectively. In general, the composition of the smaller particles would be expected to be more organic (Zhang et al., 2005b), suggesting that the values derived from the bulk analysis may be biased low. These last two cases also allow us to evaluate the uncertainties in the event that the AMS preferentially under- or over-measured either the inorganic or organic component of the aerosol.

In general, uncertainties associated with the chemical composition are individually similar to the uncertainty determined statistically for $\kappa_{\mathrm{Ox}}$ and $a$, although the cumulative effects of multiple cases occurring at once are not quantified. The uncertainties are relatively low for each individual case because the composition of the aerosol is, for the majority of the study, $>25 \%$ inorganic and $<25 \%$ unoxygenated organic in mass, making the $\mathrm{CCN}$-activity fairly insensitive to changes in the chemical composition (i.e. upper right section of Fig. 5 in Chang et al., 2007). However, it is possible that uncertainties in multiple factors combine to reduce the overall apparent uncertainty. 
Table 3. Sensitivity analysis for potential uncertainties in the two calculaton methods. See text for description of each case.

\begin{tabular}{llcc}
\hline Case & Description & Uncertainty in $\kappa_{\mathrm{Ox}}$ & Uncertainty in $a$ \\
\hline 1 & $0.04 \%$ uncertainty in supersaturation & \pm 0.06 & \pm 0.07 \\
2 & $5 \%$ uncertainty in SMPS size & \pm 0.04 & \pm 0.06 \\
3 & $10 \%$ uncertainty in density of unoxygenated component & \pm 0.01 & \pm 0.01 \\
4 & $10 \%$ uncertainty in density of oxygenated component & $<0.01$ & \pm 0.01 \\
5 & BBOA as insoluble & +0.04 & - \\
6 & 0.1 increase in mass fraction of oxygenated organic fraction & +0.07 & - \\
7 & 0.1 decrease in mass fraction of oxygenated organic fraction & -0.05 & - \\
8 & 20\% uncertainty in O/C & - & \pm 0.06 \\
9 & EC/OM ratio =0.2 & +0.05 & +0.05 \\
10 & Ammonium nitrate separate & $<0.01$ & -0.01 \\
11 & Composition of small particles & +0.08 & +0.11 \\
12 & $50 \%$ increase in organic mass & +0.04 & +0.05 \\
13 & $50 \%$ increase in inorganic mass & -0.06 & -0.09 \\
14 & $10 \%$ decrease in surface tension & -0.08 & -0.12 \\
15 & $20 \%$ decrease in surface tension & -0.16 & -0.22 \\
\hline
\end{tabular}

Finally, Cases 14 and 15 show the sensitivity of the results to a decrease in the surface tension of the droplet by $10 \%$ and $20 \%$, respectively, which has the greatest effect on the predicted values. Reductions in the droplet surface tension result in the greatest uncertainty since they affect the exponential term in Eq. (1). However, the $\kappa$-Köhler model usually uses the surface tension of water and $\kappa$ is varied to account for aerosol properties (Petters and Kreidenweis, 2007). As such, the uncertainties in Cases 14 and 15 are presented to gain general understanding in the sensitivity of our results.

\subsection{Comparison with literature values}

A theoretical compound that could be representative of the oxygenated component of the aerosol would be SOA. These typically have a van't Hoff factor of one, a molecular weight that can be approximated by $150 \mathrm{~g} \mathrm{~mol}^{-1}$ (e.g. small diacids with molecular weights of $104 \mathrm{~g} \mathrm{~mol}^{-1}$ for malonic acid to $132 \mathrm{~g} \mathrm{~mol}^{-1}$ for glutaric acid and monoterpene oxidation products such as norpinic acid, $172 \mathrm{~g} \mathrm{~mol}^{-1}$, and pinic acid, $214 \mathrm{~g} \mathrm{~mol}^{-1}$ ) and a density of $1500 \mathrm{~kg} \mathrm{~m}^{-3}$ (1400$1600 \mathrm{~kg} \mathrm{~m}^{-3}$ for glutaric and malonic acids, respectively (Weast et al., 1983) and $1500 \mathrm{~kg} \mathrm{~m}^{-3}$ for oxidation products of monoterpenes, Kostenidou et al., 2007). For this theoretical compound, $\kappa$ is calculated to be 0.18 from Eq. (3). This is consistent with the 0.22 calculated for $\kappa_{\mathrm{ox}}$, suggesting that its hygroscopicity could be explained by these reasonable assumptions in physical properties.

Studies of SOA formed in smog chambers with monoterpene VOC precursors have measured the $\kappa$ of the entire aerosol to be in the range of 0.04-0.14 (Duplissy et al., 2008; Engelhart et al., 2008; Prenni et al., 2007; Wex et al., 2009) as compared to 0.22 for the oxygenated factors measured in this study. However, chamber-generated aerosols are typically less oxidised than the OOA components of ambient aerosols (in particular, the OOA-1 (LV-OOA) component, $\mathrm{Ng}$ et al., 2010), suggesting that they may not be completely representative of the oxygenated component of ambient aerosols. This could in part be due to higher precursor concentrations, perhaps arising from increased particle-phase partitioning of the more volatile, less oxygenated and hygroscopic components that can arise at high mass loadings frequently used in chamber experiments (Duplissy et al., 2008; Kostenidou et al., 2009; Shilling et al., 2009). The difference could also arise from the limited number of SOA precursors being used in the chamber experiments. Finally, it may not be entirely valid to compare the $\kappa$ for OOA factors for aerosol measured in the field to that of lab aerosol, since the latter may have different molecular weights and solubilities, and may not be a fully oxygenated aerosol, i.e. it may have some saturated hydrocarbon functional groups that lower its hygroscopicity. As such, it is not surprising that the ambient data are slightly more hygroscopic than the results from the chamber studies.

For example, and to be more specific, in an $\mathrm{OH}$ oxidation study performed by Duplissy et al. (2008), $\kappa$ for the entire aerosol was found to be 0.12 for initial precursor concentrations of $10 \mathrm{ppb}$ for $\alpha$-pinene and $3.8 \mathrm{ppbv} \mathrm{NO}_{\mathrm{x}}$. The fraction of the organic signal at $\mathrm{m} / \mathrm{z} 44$ was approximately 0.12 $(\mathrm{O} / \mathrm{C} \approx 0.54)$, which would result in a $\kappa$ of 0.16 , calculated using Eq. (7). Similarly, in an ozonolysis study of $\alpha$-pinene by George and Abbatt (2010), the ratio of $m / z 44$ to total organic ranged from 0.046 to $0.063(\mathrm{O} / \mathrm{C}=0.26$ to 0.32$)$, corresponding to a calculated range of $\kappa$ for the entire aerosol from 0.08 to 0.09 , which is comparable to the measured values of 0.098 to 0.12 . In both cases, the resulting $\kappa$ for the entire aerosol is consistently lower than the 0.22 found for the OOA components in this study, where the $m / z 44$ to total organic fraction was 0.10 to 0.19 . 
Other studies that have attempted to quantify $\kappa_{\text {org }}$ in the field found that using a value of 0.1 can adequately describe the $\mathrm{CCN}$-activity of the aerosol at cloud-level (Wang et al., 2008) and in the Amazon rainforest (Gunthe et al., 2009). This is comparable to the campaign-wide average for this study of 0.15 for $\kappa_{\text {org }}$, calculated using both Eqs. (5) and (7). However, if a constant $\kappa_{\text {org }}$ of 0.15 is used in our analysis, the organic-rich particles tend to be slightly overpredicted $\left(R_{\mathrm{CCN}}=1.21 \pm 0.01\right)$ compared to the inorganic-rich particles $\left(R_{\mathrm{CCN}}=1.18 \pm 0.01\right)$.

Others have simplified aerosol hygroscopicity even further by using a single $\kappa$ for the whole aerosol over an entire study. This would yield an average $\kappa$ of 0.3 , which is consistent with the 0.3 value that was found in continental China (Rose et al., 2010). However, if this constant $\kappa$ is applied to all the data, the $\mathrm{CCN}$ numbers are significantly overpredicted when the aerosol is dominated by the organic-rich fraction $\left(R_{\mathrm{CCN}}=1.31 \pm 0.01\right)$ compared to times when the aerosol is mostly inorganic $\left(R_{\mathrm{CCN}}=1.10 \pm 0.01\right)$ (Fig. 1c). This indicates that more chemical information is needed in order to accurately predict the $\mathrm{CCN}$-activity of ambient aerosols, as opposed to the simplest approach of assuming that the chemical composition is constant and that one value for $\kappa$ can be applied to all aerosol types.

\section{Conclusions}

In this analysis we use the degree of oxygenation of the organic fraction of continental aerosol to determine its overall hygroscopicity. Two methods are used to determine the degree of oxygenation, factors elucidated from PMF analysis and from the values of $\mathrm{O} / \mathrm{C}$, both of which yield a similar result in terms of the overall $\kappa_{\mathrm{org}}$. Analysis of the entire study found that a $\kappa_{\mathrm{Ox}}$ of $0.22 \pm 0.04$ is suitable if we assume that the unoxygenated HOA component is non-hygroscopic. This overall value is similar to those for two of the three specific time periods for the study. It is important to point out the one air regime when this relationship does not hold, referred to as the Pre-Anthropogenic period, which we believe was characterised by aged continental aerosol mixed with fresh traffic emissions. At this point, we can speculate that this may have been due to a surface coating or oligomerization process that inhibited water uptake, but clearly the mechanism for this suppression is not well-understood. Additional studies to test the generality of the relationships with the hygroscopicity of the oxygenated organic components as presented in the paper are needed. For example, if fresh traffic emissions are again observed to suppress the apparent hygroscopicity then the possibility of a kinetic inhibition from the presence of high levels of unprocessed HOA components may prove to be a viable mechanism.

By assuming that the hygroscopicity of the organic component scales linearly with the $\mathrm{O} / \mathrm{C}$, we find that $\kappa_{\text {org }}=(0.29 \pm 0.05) \cdot(\mathrm{O} / \mathrm{C})$ for the full study $(0.3<\mathrm{O} / \mathrm{C}<0.6)$, although the degree of oxygenation of the aerosol in this study was limited in range and further studies in locations with aerosols of different degrees of oxygenation are needed to determine if this relationship is widely applicable.

With the widespread use of the AMS and subsequent PMF analysis to characterise ambient aerosol composition, these results are especially relevant in light of the limitations inherent to climate models that can only incorporate a limited number of aerosol components. Specifically, these models frequently only incorporate a hydrophobic and a hydrophilic organic aerosol species, similar in nature to the HOA and OOA AMS factors. By associating specific $\kappa$ to these two aerosol types, as derived from analyses of the type presented in this paper, an empirically-based hygroscopicity constant for the climate model organic aerosol component can be determined.

Acknowledgements. The authors would like to acknowledge significant support from F. Froude and the staff at the Centre for Atmospheric Research Experiments, Helena Dryfhout-Clark for the meteorological information and Environment Canada. Thanks also to M. McGuire for helpful discussions. Funding for the study came from NSERC, including a CGS-D awarded to R. Chang, and CFCAS, through the Cloud Aerosol Feedbacks and Climate Network. Partial infrastructure funding came from CFI and OIT. The authors also gratefully acknowledge the NOAA Air Resources Laboratory (ARL) for the provision of the HYSPLIT transport and dispersion model and READY website (http://www.arl.noaa.gov/ready.html) used in this publication. Finally, the authors would like to thank the reviewers for their helpful comments.

Edited by: A. Petzold

\section{References}

Abbatt, J., Broekhuizen, K., and Pradeep Kumar, P.: Cloud condensation nucleus activity of internally mixed ammonium sulfate/organic acid aerosol particles, Atmos. Environ., 39, 47674778, 2005.

Aiken, A. C., DeCarlo, P. F., and Jimenez, J. L.: Elemental Analysis of Organic Species with Electron Ionization High-Resolution Mass Spectrometry, Anal. Chem., 79, 8350-8353, 2007.

Aiken, A. C., Decarlo, P. F., Kroll, J. H., Worsnop, D. R., Huffman, J. A., Docherty, K. S., Ulbrich, I. M., Mohr, C., Kimmel, J. R., Sueper, D., Sun, Y., Zhang, Q., Trimborn, A., Northway, M., Ziemann, P. J., Canagaratna, M. R., Onasch, T. B., Alfarra, M. R., Prévôt, A. S. H., Dommen, J., J., D., Metzger, A., Baltensperger, U., and Jimenez, J. L.: O/C and OM/OC ratios of primary, secondary, and ambient organic aerosols with high-resolution timeof-flight aerosol mass spectrometry, Environ. Sci. Technol., 42, 4478-4485, 2008.

Albrecht, B.: Aerosols, Cloud Microphysics, and Fractional Cloudiness, Science, 245, 1227-1230, 1989.

Allan, J. D., Williams, P. I., Morgan, W. T., Martin, C. L., Flynn, M. J., Lee, J., Nemitz, E., Phillips, G. J., Gallagher, M. W., and Coe, H.: Contributions from transport, solid fuel burning and cooking to primary organic aerosols in two UK cities, Atmos. Chem. Phys., 10, 647-668, doi:10.5194/acp-10-647-2010, 2010. 
Bilde, M. and Svenningsson, B.: CCN activation of slightly soluble organics: the importance of small amounts of inorganic salt and particle phase, Tellus B, 56, 128-134, 2004.

Broekhuizen, K., Pradeep Kumar, P., and Abbatt, J. P. D.: Partially soluble organics as cloud condensation nuclei: Role of trace soluble and surface active species, Geophys. Res. Lett., 31, L01107, doi:10.1029/2003GL018203, 2004a.

Broekhuizen, K., Chang, R.Y.-W., Leaitch, W. R., Li, S.-M., and Abbatt, J. P. D.: Closure between measured and modeled cloud condensation nuclei (CCN) using size-resolved aerosol compositions in downtown Toronto, Atmos. Chem. Phys., 6, 2513-2524, doi:10.5194/acp-6-2513-2006, 2006.

Broekhuizen, K. E., Thornberry, T., Pradeep Kumar, P., and Abbatt, J. P. D.: Formation of cloud condensation nuclei by oxidative processing: Unsaturated fatty acids, J. Geophys. Res., 109, D24206, doi:10.1029/2004JD005298, 2004b.

Chan, T. W., Huang, L., Leaitch, W. R., Sharma, S., Brook, J. R., Slowik, J. G., Abbatt, J. P. D., Brickell, P. C., Liggio, J., Li, S.M., and Moosmller, H.: Observations of OM/OC and specific attenuation coefficients (SAC) in ambient fine PM at a rural site in central Ontario, Canada, Atmos. Chem. Phys., 10, 2393-2411, doi:10.5194/acp-10-2393-2010, 2010.

Chang, R.-W., Liu, P., Leaitch, W., and Abbatt, J.: Comparison between measured and predicted CCN concentrations at Egbert, Ontario: Focus on the organic aerosol fraction at a semi-rural site, Atmos. Environ., 41, 8172-8182, 2007.

Chung, S. H. and Seinfeld, J. H.: Global distribution and climate forcing of carbonaceous aerosols, J. Geophys. Res., 107(D19), 4407, doi:10.1029/2001JD001397, 2002.

Clegg, S., Milioto, S., and Palmer, D.: Osmotic and Activity Coefficients of Aqueous $\left(\mathrm{NH}_{4}\right)_{2} \mathrm{SO}_{4}$ as a Function of Temperature, and Aqueous $\left(\mathrm{NH}_{4}\right)_{2} \mathrm{SO}_{4}-\mathrm{H}_{2} \mathrm{SO}_{4}$ Mixtures at $298.15 \mathrm{~K}$ and 323.15 K, J. Chem. Eng. Data, 41, 455-467, 1996.

Clegg, S., Brimblecombe, P., and Wexler, A.: A thermodynamic model of the system $\mathrm{H}^{+}-\mathrm{NH}_{4}^{+}-\mathrm{Na}^{+}-\mathrm{SO}_{4}^{2-}-\mathrm{NO}_{3}^{-}-\mathrm{Cl}^{-}-\mathrm{H}_{2} \mathrm{O}$ at 298.15 K, J. Phys. Chem. A, 102, 2155-2171, 1998.

Cooke, W. F. and Wilson, J. J. N.: A global black carbon aerosol model, J. Geophys. Res., 101, 19395-19409, 1996.

Cubison, M. J., Ervens, B., Feingold, G., Docherty, K. S., Ulbrich, I. M., Shields, L., Prather, K., Hering, S., and Jimenez, J. L.: The influence of chemical composition and mixing state of Los Angeles urban aerosol on CCN number and cloud properties, Atmos. Chem. Phys., 8, 5649-5667, doi:10.5194/acp-8-5649-2008, 2008.

Cylinder Lube 1000: Cylinder Lube 1000, MSDS NO. NOC7485, NOCO Energy Corp., online available at: http://www.noco.com/ NOCO-MSDS/Cylinder_Lube_1000.htm, access: 16 February 2010, 2008.

de Gouw, J. and Warneke, C.: Measurements of volatile organic compounds in the earths atmosphere using proton-transferreaction mass spectrometry, Mass Spec. Rev., 26, 223-257, 2007.

de Gouw, J. A., Middlebrook, A. M., Warneke, C., Goldan, P. D., Kuster, W. C., Roberts, J. M., Fehsenfeld, F. C., Worsnop, D. R., Canagaratna, M. R., Pszenny, A. A. P., Keene, W. C., Marchewka, M., Bertman, S. B., and Bates, T. S.: Budget of organic carbon in a polluted atmosphere: Results from the New England Air Quality Study in 2002, J. Geophys. Res., 110, D16305, doi:10.1029/2004JD005623, 2005.
Draxler, R. R. and Rolph, G. D.: HYSPLIT (HYbrid Single-Particle Lagrangian Integrated Trajectory) Model access via NOAA ARL READY Website (http://www.arl.noaa.gov/ready/hysplit4.html), access: 21 September 2009, 2003.

Drewnick, F., Hings, S. S., DeCarlo, P., Jayne, J. T., Gonin, M., Fuhrer, K., Weimer, S., Jimenez, J. L., Demerjian, K. L., Borrmann, S., and Worsnop, D. R.: A new time-of-flight aerosol mass spectrometer (TOF-AMS) - Instrument description and first field deployment, Aerosol Sci. Technol., 39, 637-658, 2005.

Duplissy, J., Gysel, M., Alfarra, M. R., Dommen, J., Metzger, A., Prévôt, A. S. H., Weingartner, E., Laaksonen, A., Raatikainen, T., Good, N., Turner, S. F., McFiggans, G., and Baltensperger, U.: Cloud forming potential of secondary organic aerosol under near atmospheric conditions, Geophys. Res. Lett., 35, L03818, doi:10.1029/2007GL031075, 2008.

Engelhart, G. J., Asa-Awuku, A., Nenes, A., and Pandis, S. N.: $\mathrm{CCN}$ activity and droplet growth kinetics of fresh and aged monoterpene secondary organic aerosol, Atmos. Chem. Phys., 8, 3937-3949, doi:10.5194/acp-8-3937-2008, 2008.

Ervens, B., Cubison, M., Andrews, E., Feingold, G., Ogren, J. A., Jimenez, J. L., DeCarlo, P. F., and Nenes, A.: Prediction of cloud condensation nucleus number concentration using measurements of aerosol size distributions and composition and light scattering enhancement due to humidity, J. Geophys. Res., 112, D10S32, doi:10.1029/2006JD007426, 2007.

Ervens, B., Cubison, M. J., Andrews, E., Feingold, G., Ogren, J. A., Jimenez, J. L., Quinn, P. K., Bates, T. S., Wang, J., Zhang, Q., Coe, H., Flynn, M., and Allan, J. D.: CCN predictions using simplified assumptions of organic aerosol composition and mixing state: a synthesis from six different locations, Atmos. Chem. Phys., 10, 4795-4807, doi:10.5194/acp-10-4795-2010, 2010.

Farmer, D. K., Matsunaga, A., Docherty, K. S., Surratt, J. D., Seinfeld, J. H., Ziemann, P. J., and Jimenez, J. L.: Response of an aerosol mass spectrometer to organonitrates and organosulfates and implications for atmospheric chemistry, P. Natl. Acad. Sci., 107(15), 6670-6675, doi:10.1073/pnas.0912340107, 2010.

George, I. J. and Abbatt, J. P. D.: Chemical evolution of secondary organic aerosol from $\mathrm{OH}$-initiated heterogeneous oxidation, Atmos. Chem. Phys. Discuss., 10, 3265-3300, doi:10.5194/acpd10-3265-2010, 2010.

George, I. J., Chang, R. Y.-W., Danov, V., Vlasenko, A., and Abbatt, J. P. D.: Modification of cloud condensation nucleus activity of organic aerosols by hydroxyl radical heterogeneous oxidation, Atmos. Environ., 43, 5038-5045, 2009.

Gunthe, S. S., King, S. M., Rose, D., Chen, Q., Roldin, P., Farmer, D. K., Jimenez, J. L., Artaxo, P., Andreae, M. O., Martin, S. T., and Pöschl, U.: Cloud condensation nuclei in pristine tropical rainforest air of Amazonia: size-resolved measurements and modeling of atmospheric aerosol composition and CCN activity, Atmos. Chem. Phys., 9, 7551-7575, doi:10.5194/acp-9-75512009, 2009.

Jacobson, M. C., Hansson, H.-C., Noone, K. J., and Charlson, R. J.: Organic Atmospheric Aerosols: Review and State of the Science, Rev. Geophys., 38, 267-294, 2000.

Jayne, J., Leard, D., Zhang, X., Davidovits, P., Smith, K., Kolb, C., and Worsnop, D.: Development of an Aerosol Mass Spectrometer for Size and Composition Analysis of Submicron Particles, Aerosol Sci. Tech., 33, 49-70, 2000. 
Jimenez, J., Jayne, J., Shi, Q., Kolb, C., Worsnop, D., Yourshaw, I., Seinfeld, J., Flagan, R., Zhang, X., Smith, K., Morris, J., and Davidovits, P.: Ambient aerosol sampling using the Aerodyne Aerosol Mass Spectrometer, J. Geophys. Res., 108(D7), 8425, doi:10.1029/2001JD001213, 2003.

Jimenez, J. L., Canagaratna, M. R., Donahue, N. M., Prévôt, A. S. H., Zhang, Q., Kroll, J. H., DeCarlo, P. F., Allan, J. D., Coe, H., Ng, N. L., Aiken, A. C., Docherty, K. S., Ulbrich, I. M., Grieshop, A. P., Robinson, A. L., Duplissy, J., Smith, J. D., Wilson, K. R., Lanz, V. A., Hueglin, C., Sun, Y. L., Tian, J., Laaksonen, A., Raatikainen, T., Rautiainen, J., Vaattovaara, P., Ehn, M., Kulmala, M., Tomlinson, J. M., Collins, D. R., Cubison, M. J., , Dunlea, E. J., Huffman, J. A., Onasch, T. B., Alfarra, M. R., Williams, P. I., Bower, K., Kondo, Y., Schneider, J., Drewnick, F., Borrmann, S., Weimer, S., Demerjian, K., Salcedo, D., Cottrell, L., Griffin, R., Takami, A., Miyoshi, T., Hatakeyama, S., Shimono, A., Sun, J. Y., Zhang, Y. M., Dzepina, K., Kimmel, J. R., Sueper, D., Jayne, J. T., Herndon, S. C., Trimborn, A. M., Williams, L. R., Wood, E. C., Middlebrook, A. M., Kolb, C. E., Baltensperger, U., and Worsnop, D. R.: Evolution of Organic Aerosols in the Atmosphere, Science, 326, 1525-1529, doi:10.1126/science.1180353, 2009.

Jurányi, Z., Gysel, M., Duplissy, J., Weingartner, E., Tritscher, T., Dommen, J., Henning, S., Ziese, M., Kiselev, A., Stratmann, F., George, I., and Baltensperger, U.: Influence of gasto-particle partitioning on the hygroscopic and droplet activation behaviour of $\alpha$-pinene secondary organic aerosol, Phys. Chem. Chem. Phys., 11, 8091-8097, 2009.

Köhler, H.: The nucleus in and the growth of hygroscopic droplets, Trans. Faraday Soc., 32, 1152-1161, 1936.

Kostenidou, E., Pathak, R. K., and Pandis, S. N.: An Algorithm for the Calculation of Secondary Organic Aerosol Density Combining AMS and SMPS Data, Aerosol Sci. Tech., 41, 1002-1010, 2007.

Kostenidou, E., Lee, B. H., Engelhart, G. J., Pierce, J. R., and Pandis, S. N.: Mass Spectra Deconvolution of Low, Medium, and High Volatility Biogenic Secondary Organic Aerosol, Environ. Sci. Technol., 43, 4884-4889, 2009.

Lance, S., Nenes, A., Mazzoleni, C., Dubey, M. K., Gates, H., Varutbangkul, V., Rissman, T. A., Murphy, S. M., Sorroshian, A., Flagan, R. C., Seinfeld, J. H., and Jonsson, H. H.: Cloud condensation nuclei activity, closure, and droplet growth kinetics of Houston aerosol during the Gulf of Mexico Atmospheric Composition and Climate Study (GoMACCS), J. Geophys. Res., 114, D00F15, doi:10.1029/2008JD011699, 2009.

Lanz, V. A., Alfarra, M. R., Baltensperger, U., Buchmann, B., Hueglin, C., and Prévôt, A. S. H.: Source apportionment of submicron organic aerosols at an urban site by factor analytical modelling of aerosol mass spectra, Atmos. Chem. Phys., 7, 1503-1522, doi:10.5194/acp-7-1503-2007, 2007.

Lohmann, U., Feichter, J., Chuang, C. C., and Penner, J. E.: Prediction of the number of cloud droplets in the ECHAM GCM, J. Geophys. Res., 104, 9169-9198, 1999.

McFiggans, G., Alfarra, M. R., Allan, J., Bower, K., Coe, H., Cubison, M., Topping, D., Williams, P., Decesari, S., Facchini, C., and Fuzzi, S.: Simplification of the representation of the organic component of atmospheric particulates, Faraday Discuss., 130, 341-362, 2005.
Medina, J., Nenes, A., Sotiropoulou, R.-E. P., Cottrell, L. D., Ziemba, L. D., Beckman, P. J., and Griffin, R. J.: Cloud condensation nuclei closure during the International Consortium for Atmospheric Research on Transport and Transformation 2004 campaign: Effects of size-resolved composition, J. Geophys. Res., 112, D10S31, doi:10.1029/2006JD007588, 2007.

Ng, N. L., Canagaratna, M. R., Zhang, Q., Jimenez, J. L., Tian, J., Ulbrich, I. M., Kroll, J. H., Docherty, K. S., Chhabra, P. S., Bahreini, R., Murphy, S. M., Seinfeld, J. H., Hildebrandt, L., Donahue, N. M., DeCarlo, P. F., Lanz, V. A., Prévôt, A. S. H., Dinar, E., Rudich, Y., and Worsnop, D. R.: Organic aerosol components observed in Northern Hemispheric datasets from Aerosol Mass Spectrometry, Atmos. Chem. Phys., 10, 46254641, doi:10.5194/acp-10-4625-2010, 2010.

Paatero, P.: Least squares formulation of robus non-negative factor analysis, Chemometr. Intell. Lab., 37, 23-35, 1997.

Paatero, P. and Tapper, U.: Positive matrix factorization: A nonnegative factor model with optimal utilization of error estimates of data values, Environmetrics, 5, 111-126, 1994.

Petters, M., Carrico, C., Kreidenweis, S. M., Prenni, A., DeMott, P., Collett, J., and Moosmuller, H.: Cloud Condensation Nucleation Activity of Biomass Burning Aerosol, J. Geophys. Res., 114, D22205, doi:10.1029/2009JD012353, 2009a.

Petters, M. D. and Kreidenweis, S. M.: A single parameter representation of hygroscopic growth and cloud condensation nucleus activity, Atmos. Chem. Phys., 7, 1961-1971, doi:10.5194/acp-71961-2007, 2007.

Petters, M. D. and Kreidenweis, S. M.: A single parameter representation of hygroscopic growth and cloud condensation nucleus activity Part 2: Including solubility, Atmos. Chem. Phys., 8, 6273-6279, doi:10.5194/acp-8-6273-2008, 2008.

Petters, M. D., Prenni, A. J., Kreidenweis, S. M., DeMott, P. J., Matsunaga, A., Lim, Y. B., and Ziemann, P. J.: Chemical aging and the hydrophobic-to-hydrophilic conversion of carbonaceous aerosol, Geophys. Res. Lett., 33, L24806, doi:10.1029/2006GL027249, 2006.

Petters, M. D., Wex, H., Carrico, C. M., Hallbauer, E., Massling, A., McMeeking, G. R., Poulain, L., Wu, Z., Kreidenweis, S. M., and Stratmann, F.: Towards closing the gap between hygroscopic growth and activation for secondary organic aerosol - Part 2: Theoretical approaches, Atmos. Chem. Phys., 9, 3999-4009, doi:10.5194/acp-9-3999-2009, 2009b.

Pradeep Kumar, P., Broekhuizen, K., and Abbatt, J. P. D.: Organic acids as cloud condensation nuclei: Laboratory studies of highly soluble and insoluble species, Atmos. Chem. Phys., 3, 509-520, doi:10.5194/acp-3-509-2003, 2003.

Prenni, A. J., Petters, M. D., Kreidenweis, S. M., DeMott, P. J., and Ziemann, P. J.: Cloud droplet activation of secondary aerosol, J. Geophys. Res., 112, D10223, doi:10.1029/2006JD007963, 2007.

Quinn, P. K., Bates, T. S., Coffman, D. J., and Covert, D. S.: Influence of particle size and chemistry on the cloud nucleating properties of aerosols, Atmos. Chem. Phys., 8, 1029-1042, doi:10.5194/acp-8-1029-2008, 2008.

Raatikainen, T., Vaattovaara, P., Tiitta, P., Miettinen, P., Rautiainen, J., Ehn, M., Kulmala, M., Laaksonen, A., and Worsnop, D. R.: Physicochemical properties and origin of organic groups detected in boreal forest using an aerosol mass spectrometer, Atmos. Chem. Phys., 10, 2063-2077, doi:10.5194/acp-10-20632010, 2010. 
Raymond, T. M. and Pandis, S. N.: Cloud activation of single-component organic aerosol particles, J. Geophys. Res., 107(D24), 4787, doi:10.1029/2002JD002159, 2002.

Raymond, T. M. and Pandis, S. N.: Formation of cloud droplets by multicomponent organic particles, J. Geophys. Res., 108(D15), 4469, doi:10.1029/2003JD003503, 2003.

Roberts, G., Artaxo, P., Zhou, J., Swietlicki, E., and Andreae, M. O.: Sensitivity of CCN spectra on chemical and physical properties of aerosol: A case study from the Amazon Basin, J. Geophys. Res., 107(D20), 8070, doi:10.1029/2001JD000583, 2002.

Roberts, J. M., Fehsenfeld, F. C., Liu, S. C., Bollinger, M. J., Hahn, C., Albritton, D. L., and Sievers, R. E.: Measurements of aromatic hydrocarbon ratios and NOx concentrations in the rural troposphere: Observation of air mass photochemical aging and NOx removal, Atmos. Environ., 18, 2421-2432, 1984.

Rolph, G. D.: Real-time Environmental Applications and Display sYstem (READY) Website (http://www.arl.noaa.gov/ready/ hysplit4.html), access: 21 September 2009, 2003.

Rose, D., Nowak, A., Achtert, P., Wiedensohler, A., Hu, M., Shao, M., Zhang, Y., Andreae, M. O., and Pöschl, U.: Cloud condensation nuclei in polluted air and biomass burning smoke near the mega-city Guangzhou, China - Part 1: Size-resolved measurements and implications for the modeling of aerosol particle hygroscopicity and CCN activity, Atmos. Chem. Phys., 10, 33653383, doi:10.5194/acp-10-3365-2010, 2010.

Rupakheti, M., Leaitch, W., Lohmann, U., Hayden, K., Brickell, P., Lu, G., Li, S.-M., Toom-Sauntry, D., Bottenheim, J., Brook, J., Vet, R., Jayne, J., and Worsnop, D.: An Intensive Study of the Size and Composition of Submicron Atmospheric Aerosols at a Rural Site in Ontario, Canada, Aerosol Sci. Tech., 39, 722-736, 2005.

Saxena, P. and Hildemann, L. M.: Water-soluble organics in atmospheric particles: A critical review of the literature and application of thermodynamics to identify candidate compounds, J. Atmos. Chem., 24, 57-109, 1996.

Saxena, V. K., Burford, J. N., and Kassner Jr., J. L.: Operation of a Thermal Diffusion Chamber for Measurements on Cloud Condensation Nuclei, J. Atmos. Sci., 27, 73-80, 1970.

Shantz, N. C., Chang, R. Y.-W., Slowik, J. G., Vlasenko, A., Abbatt, J. P. D., and Leaitch, W. R.: Slower CCN growth kinetics of anthropogenic aerosol compared to biogenic aerosol observed at a rural site, Atmos. Chem. Phys., 10, 299-312, doi:10.5194/acp10-299-2010, 2010.

Shilling, J. E., King, S. M., Mochida, M., Worsnop, D. R., and Martin, S. T.: Mass Spectral Evidence That Small Changes in Composition Caused by Oxidative Aging Processes Alter Aerosol CCN Properties, J. Phys. Chem. A., 111, 3358-3368, 2007.

Shilling, J. E., Chen, Q., King, S. M., Rosenoern, T., Kroll, J. H., Worsnop, D. R., DeCarlo, P. F., Aiken, A. C., Sueper, D., Jimenez, J. L., and Martin, S. T.: Loading-dependent elemental composition of a-pinene SOA particles, Atmos. Chem. Phys., 9, 771-782, doi:10.5194/acp-9-771-2009, 2009.

Shinozuka, Y., Clarke, A. D., DeCarlo, P. F., Jimenez, J. L., Dunlea, E. J., Roberts, G. C., Tomlinson, J. M., Collins, D. R., Howell, S. G., Kapustin, V. N., McNaughton, C. S., and Zhou, J.: Aerosol optical properties relevant to regional remote sensing of $\mathrm{CCN}$ activity and links to their organic mass fraction: airborne observations over Central Mexico and the US West Coast dur- ing MILAGRO/INTEX-B, Atmos. Chem. Phys., 9, 6727-6742, doi:10.5194/acp-9-6727-2009, 2009.

Slowik, J. G., Vlasenko, A., McGuire, M., Evans, G. J., and Abbatt, J. P. D.: Simultaneous factor analysis of organic particle and gas mass spectra: AMS and PTR-MS measurements at an urban site, Atmos. Chem. Phys., 10, 1969-1988, doi:10.5194/acp-10-19692010, 2010.

Slowik, J. G., Stroud, C., Bottenheim, J. W., Brickell, P. C., Chang, R. Y.-W., Liggio, J., Makar, P. A., Martin, R. V., Moran, M. D., Shantz, N. C., Sjostedt, S. J., van Donkelaar, A., Vlasenko, A., Wiebe, H. A., Xia, A. G., Zhang, J., Leaitch, W. R., and Abbatt, J. P. D.: Characterization of a large biogenic secondary organic aerosol event from eastern Canadian forests, Atmos. Chem. Phys., 10, 2825-2845, doi:10.5194/acp-10-2825-2010, 2010.

Solomon, S., Qin, D., Manning, M., Chen, Z., Marquis, M., Averyt, K. B., Tignor, M., and Miller, H. (eds.): IPCC, 2007: Summary for Policymakers, Climate Change 2007: The Physical Science Basis. Contribution of Working Group I to the Fourth Assessment Report of the Intergovernmental Panel on Climate Change, Cambridge University Press, New York, 2007.

Stroud, C. A., Nenes, A., Jimenez, J. L., DeCarlo, P. F., Huffman, J. A., Bruintjes, R., Nemitz, E., Delia, A. E., Toohey, D. W., Guenther, A. B., and Nandi, S.: Cloud Activating Properties of Aerosol Observed during CELTIC, J. Atmos. Sci., 64, 441-459, 2007.

Twomey, S.: The Influence of Pollution on the Shortwave Albedo of Clouds, J. Atmos. Sci., 34, 1149-1152, 1977.

Ulbrich, I. M., Canagaratna, M. R., Zhang, Q., Worsnop, D. R., and Jimenez, J. L.: Interpretation of organic components from Positive Matrix Factorization of aerosol mass spectrometric data, Atmos. Chem. Phys., 9, 2891-2918, doi:10.5194/acp-9-2891-2009, 2009.

Vlasenko, A., Slowik, J. G., Bottenheim, J., Brickell, P., Chang, R.W., Macdonald, A., Shantz, N., Sjostedt, S., Wiebe, H., Leaitch, W., and Abbatt, J.: Measurements of VOCs by Proton-TransferReaction Mass Spectrometry at a Rural Ontario Site: Sources and Correlation to Aerosol Composition, J. Geophys. Res., 114, D21305, doi:10.1029/2009JD012025, 2009.

Wang, J., Lee, Y.-N., Daum, P. H., Jayne, J., and Alexander, M. L.: Effects of aerosol organics on cloud condensation nucleus (CCN) concentration and first indirect aerosol effect, Atmos. Chem. Phys., 8, 6325-6339, doi:10.5194/acp-8-6325-2008, 2008.

Weast, R. C., Astle, M. J., and Beyer, W. H., eds.: CRC Handbook of Chemistry and Physics, 64th Edition, CRC Press, Inc., Boca Raton, Florida, 1983.

Wex, H., Petters, M. D., Carrico, C. M., Hallbauer, E., Massling, A., McMeeking, G. R., Poulain, L., Wu, Z., Kreidenweis, S. M., and Stratmann, F.: Towards closing the gap between hygroscopic growth and activation for secondary organic aerosol: Part 1 Evidence from measurements, Atmos. Chem. Phys., 9, 39873997, doi:10.5194/acp-9-3987-2009, 2009.

Wexler, A. S. and Clegg, S. L.: Atmospheric aerosol models for systems including the ions $\mathrm{H}^{+}, \mathrm{NH}_{4}^{+}, \mathrm{Na}^{+}, \mathrm{SO}_{4}^{2-}, \mathrm{NO}_{3}^{-}, \mathrm{Cl}^{-}$, $\mathrm{Br}^{-}$and $\mathrm{H}_{2} \mathrm{O}$, J. Geophys. Res., 107(D14), 4207, doi:10.1029/ 2001JD000451, 2002.

Windholz, M. (ed.): The Merck index, Tenth Edition, Merck and Co., Inc., Rahway, NJ, 1983. 
Zhang, Q., Alfarra, M. R., Worsnop, D. R., Allan, J. D., Coe, H., Canagaratna, M. R., and Jimenez, J. L.: Deconvolution and Quantification of Hydrocarbon-like and Oxygenated Organic Aerosols Based on Aerosol Mass Spectrometry, Environ. Sci. Technol., 39, 4938-4952, 2005a.

Zhang, Q., Canagaratna, M. R., Jayne, J. T., and Worsnop, D. R.: Time- and size-resolved chemical composition of submicron particles in Pittsburgh: Implications for aerosol sources and processes, J. Geophys. Res., 110, D07S09, doi:10.1029/2004JD004649, 2005b.
Zhang, Q., Jimenez, J. L., Canagaratna, M. R., Allan, J. D., Coe, H., Ulbrich, I., Alfarra, M., Takami, A., Middlebrook, A. M., Sun, Y., Dzepina, K., Dunlea, E., Docherty, K., DeCarlo, P. F., D., S., Onasch, T. B., Jayne, J., Miyoshi, T., Shimono, A., Hatakeyama, S., Takegawa, N., Kondo, Y., Schneider, J., Drewnick, F., Borrmann, S., Weimer, S., Demerjian, K., Williams, P., Bower, K., Bahreini, R., Cottrell, L., Griffin, R. J., Rautiainen, J., Sun, J., Zhang, Y., and Worsnop, D.: Ubiquity and dominance of oxygenated species in organic aerosols in anthropogenicallyinfluenced Northern Hemisphere midlatitudes, Geophys. Res. Lett., 34, L13801, doi:10.1029/2007GL029979, 2007. 